\title{
Observations of ice multiplication in a weakly convective cell embedded in supercooled mid-level stratus
}

\author{
J. Crosier ${ }^{1,2}$, K. N. Bower ${ }^{1}$, T. W. Choularton ${ }^{1}$, C. D. Westbrook ${ }^{3}$, P. J. Connolly ${ }^{1}$, Z. Q. Cui ${ }^{4}$, I. P. Crawford ${ }^{1}$, \\ G. L. Capes ${ }^{1}$, H. Coe $^{1}$, J. R. Dorsey ${ }^{1,2}$, P. I. Williams ${ }^{1,2}$, A. J. Illingworth ${ }^{3}$, M. W. Gallagher ${ }^{1}$, and A. M. Blyth ${ }^{4,2}$ \\ ${ }^{1}$ Centre for Atmospheric Science, SEAES, University of Manchester, Manchester, UK \\ ${ }^{2}$ National Centre for Atmospheric Science, University of Manchester, Manchester, UK \\ ${ }^{3}$ Department of Meteorology, University of Reading, Reading, UK \\ ${ }^{4}$ School of Earth and Environment, University of Leeds, Leeds, UK
}

Received: 3 June 2010 - Published in Atmos. Chem. Phys. Discuss.: 17 August 2010

Revised: 9 December 2010 - Accepted: 24 December 2010 - Published: 13 January 2011

\begin{abstract}
Simultaneous observations of cloud microphysical properties were obtained by in-situ aircraft measurements and ground based Radar/Lidar. Widespread mid-level stratus cloud was present below a temperature inversion $\left(\sim 5^{\circ} \mathrm{C}\right.$ magnitude) at $3.6 \mathrm{~km}$ altitude. Localised convection (peak updraft $1.5 \mathrm{~m} \mathrm{~s}^{-1}$ ) was observed $20 \mathrm{~km}$ west of the Radar station. This was associated with convergence at $2.5 \mathrm{~km}$ altitude. The convection was unable to penetrate the inversion capping the mid-level stratus.

The mid-level stratus cloud was vertically thin $(\sim 400 \mathrm{~m})$, horizontally extensive (covering $100 \mathrm{~s}$ of $\mathrm{km}$ ) and persisted for more than $24 \mathrm{~h}$. The cloud consisted of supercooled water droplets and small concentrations of large $(\sim 1 \mathrm{~mm})$ stellar/plate like ice which slowly precipitated out. This ice was nucleated at temperatures greater than $-12.2^{\circ} \mathrm{C}$ and less than $-10.0^{\circ} \mathrm{C}$, (cloud top and cloud base temperatures, respectively). No ice seeding from above the cloud layer was observed. This ice was formed by primary nucleation, either through the entrainment of efficient ice nuclei from above/below cloud, or by the slow stochastic activation of immersion freezing ice nuclei contained within the supercooled drops. Above cloud top significant concentrations of sub-micron aerosol were observed and consisted of a mixture of sulphate and carbonaceous material, a potential source of ice nuclei. Particle number concentrations (in the size range $0.1<D<3.0 \mu \mathrm{m}$ ) were measured above and below cloud in concentrations of $\sim 25 \mathrm{~cm}^{-3}$. Ice crystal concentrations in the cloud were constant at around $0.2 \mathrm{~L}^{-1}$. It is estimated that
\end{abstract}

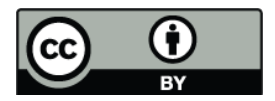

Correspondence to: J. Crosier (j.crosier@manchester.ac.uk) entrainment of aerosol particles into cloud cannot replenish the loss of ice nuclei from the cloud layer via precipitation.

Precipitation from the mid-level stratus evaporated before reaching the surface, whereas rates of up to $1 \mathrm{~mm} \mathrm{~h}^{-1}$ were observed below the convective feature. There is strong evidence for the Hallett-Mossop (HM) process of secondary ice particle production leading to the formation of the precipitation observed. This includes (1) Ice concentrations in the convective feature were more than an order of magnitude greater than the concentration of primary ice in the overlaying stratus, (2) Large concentrations of small pristine columns were observed at the $\sim-5^{\circ} \mathrm{C}$ level together with liquid water droplets and a few rimed ice particles, (3) Columns were larger and increasingly rimed at colder temperatures. Calculated ice splinter production rates are consistent with observed concentrations if the condition that only droplets greater than $24 \mu \mathrm{m}$ are capable of generating secondary ice splinters is relaxed.

This case demonstrates the importance of understanding the formation of ice at slightly supercooled temperatures, as it can lead to secondary ice production and the formation of precipitation in clouds which may not otherwise be considered as significant precipitation sources.

\section{Introduction}

Stratus clouds have an important impact on global climate as they typically have a high albedo, cover significant areas of the Earths surface and are relatively long lived (for liquid clouds see Bretherton et al., 2004; Ramanathan et al., 1989). The formation of ice in these clouds is also critical in

Published by Copernicus Publications on behalf of the European Geosciences Union. 
determining their radiative properties (Hogan et al., 2003a,b, 2004). Therefore, knowledge of the dynamical and microphysical processes leading to formation and dissipation of these clouds is important for predicting their radiative impacts and precipitation evolution.

The formation of precipitation from stratus clouds can result from both collision and coalescence of cloud droplets and also from the formation of ice. Ice which does form in stratus clouds is typically low in number concentration and is quickly precipitated due to rapid growth. The formation rate of ice in stable stratus clouds is poorly quantified or understood. Most laboratory studies of ice formation investigate the role of aerosol particles as Ice Nuclei (IN) by exposing them to changes in temperature and humidity to represent vertical ascent and then observing when a given aerosol type allows ice to form, (e.g., Mohler et al., 2006; Connolly et al., 2009).

Slightly supercooled stratus clouds are generally assumed to contain very few active ice nuclei and hence little ice would be expected to form (Meyers et al., 1992). Microphysical schemes used in Cloud Resolving Models (CRMs) and Single Column Models (SCMs) generate differences in predicted cloud microphysical properties for slightly $\left(>-15{ }^{\circ} \mathrm{C}\right)$ supercooled marine stratocumulus clouds (Klein et al., 2009). This demonstrates the need for measurements in mixed phase layer clouds in slightly supercooled conditions.

In convective clouds precipitation arises from the formation of large water drops as well as the development of ice. Convective clouds span a larger range of temperatures than stratus clouds, allowing a larger range of microphysical processes to occur. The formation of ice in convective clouds due to primary processes can cause secondary ice production (SIP) to occur without any additional IN. Splinter ejection during riming of ice crystals, known as the Hallett-Mossop process (referred to as HM) is one such SIP mechanism and is effective in the temperature range -3 to $-8^{\circ} \mathrm{C}$, being most active at $-5^{\circ} \mathrm{C}$ (Hallett and Mossop, 1974; Mossop and Hallett, 1974). It can lead to the formation of large concentrations of ice at slightly supercooled temperatures. Several aircraft and modelling studies suggest the HM process can be responsible for the formation of the majority of ice in convective clouds which span the temperature range -3 to $-8^{\circ} \mathrm{C}$ and have cloud top temperatures $>-30^{\circ} \mathrm{C}$ (HarrisHobbs and Cooper, 1987; Blyth and Latham, 1997; Hogan et al., 2002; Clark et al., 2005; Huang et al., 2008), although not all (Rangno and Hobbs, 2001). The development of convection can be inhibited by temperature inversions. SIP is an important process to understand since in marginal cases of convection, that may not otherwise penetrate through the temperature inversion, the additional latent heat energy released from ice formation may provide enough buoyancy to overcome such barriers (Clark et al., 2005).

In this study, simultaneous in-situ and remote measurements using the UK BAe146 Facility for Airborne Atmospheric Measurement (FAAM) aircraft in conjunction with the Chilbolton Facility for Atmospheric and Radio Research (CFARR) were used to examine the microphysical properties of an extensive layer of mixed-phase stratus cloud. A case is presented where the properties of a narrow lower level convective cloud feature penetrating into the overlying stratus layer cloud above was also examined in detail. The interaction between these two clouds in terms of the detailed microphysical and dynamical structure that arose is discussed. This case highlights the importance of primary ice nucleation at slightly supercooled temperatures, SIP via the HM process and the interaction and coupling of the two cloud systems on precipitation initiation.

\section{Instrumentation and sampling strategy}

The FAAM BAe146 aircraft flew in mixed-phase clouds on the 18 February 2009 (flight reference B430) in the vicinity of the CFARR ground site as part of the APPRAISE-Clouds project. CFARR is located in Southern England $\left(51.1145^{\circ} \mathrm{N}\right.$, $\left.1.4370^{\circ} \mathrm{W}\right)$. The BAe146 aircraft flew a combination of profile accents/descents, and constant altitude runs. A summary of aircraft manoeuvres during the flight is shown in Table 1. Aircraft operations were restricted by Air Traffic Control to an area to the west of CFARR, so the majority of the aircraft time was spent flying along a radial of $253^{\circ}$ from CFARR at distances ranging from $0 \mathrm{~km}$ (overpass) to $100 \mathrm{~km}$ at the furthest point. A Radar at the CFARR ground site (see below) performed Range Height Indicator (RHI) scans along the $253^{\circ}$ radial while other Radars/Lidars pointed vertically. See Fig. 1 for an overview of the flight location, as well as the location of the CFARR ground site.

\subsection{In situ measurements}

The FAAM aircraft measured meteorological parameters such as ambient pressure, temperature (di-iced and non de-iced Rosemount sensors), dew point (General Eastern chilled mirror hygrometer) and wind speed/direction. Measurements of trace gas mixing ratio ( $\mathrm{CO}$, Model AeroLaser AL5002, Ozone Model TECO TE49C and $\mathrm{NO}_{\mathrm{x}}$, TECO TE42C), aircraft position (GPS) and aerosol particles were also taken. De-iced Rosemount temperature is used in this paper as the aircraft was frequently in supercooled cloud/icing conditions. Aerosol particle size distributions $(0.1<$ Diameter $<3.0 \mu \mathrm{m})$ were measured with a wing pylon mounted Passive Cavity Aerosol Spectrometer Probe (PCASP, PMS). The submicron non-refractory aerosol chemical composition was measured using an Aerodyne Research Inc (ARI) Compact Time-of-Flight Aerosol Mass Spectrometer (C-ToF-AMS, see Canagaratna et al. (2007) for further description). The C-ToF-AMS sampled aerosol via a Rosemount inlet (Crosier et al., 2007). The C-ToFAMS is unable to detect mineral dust particles and has not been shown to be able to identify biological particles in the 


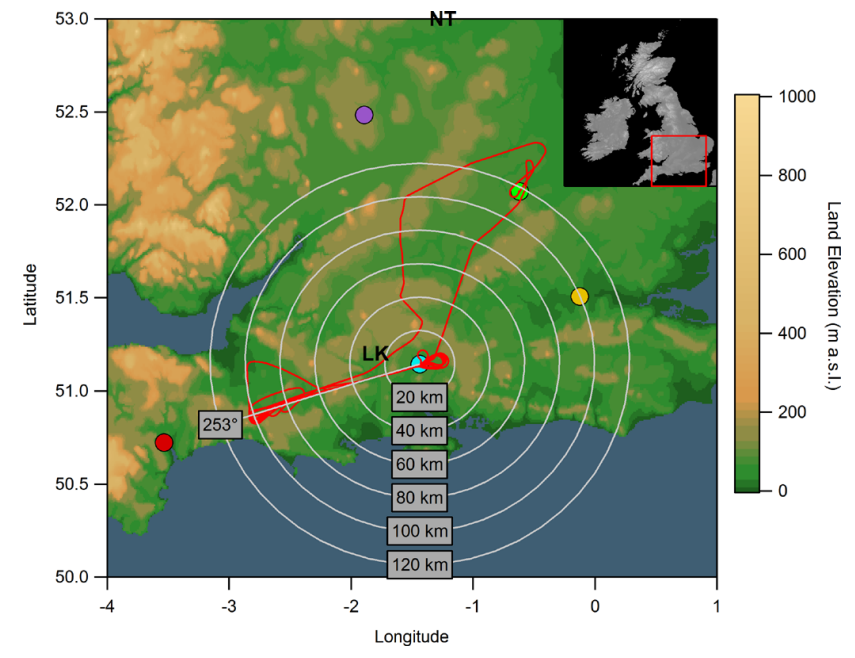

Fig. 1. Flight track of the FAAM BAe146 aircraft (in red) on 18 February 2009. Locations identified by markers include London (yellow), Exeter (red), Cranfield (green), Birmingham (purple) and the CFARR ground site (blue). Range rings at $20 \mathrm{~km}$ spacing and along the $253^{\circ}$ radial from CFARR are in grey.

ambient aerosol population. These have both been reported as efficient ice nuclei (Connolly et al., 2009; DeMott and Prenni, 2010). Therefore the C-ToF-AMS is unable to characterise an important subset of the ambient aerosol population with regards to potential Ice Nuclei.

Cloud droplets $(2<$ Diameter $<50 \mu \mathrm{m})$ were measured using a wing pylon mounted Cloud Droplet Probe (Droplet Measurement Technologies (DMT), CDP-100 Version 2) and a Forward Scattering Spectrometer Probe (FSSP, DMT SPP100). The data from the CDP are used in this paper as the FSSP and similar forward scattering (FS) probes can suffer from significant artefacts (particle shattering) in mixed-phase conditions (McFarquhar et al., 2007). This is discussed in more detail in Appendix A. The CDP has a sample area of $0.24 \mathrm{~mm}^{2}$, resulting in sample volume of $28.8 \mathrm{~cm}^{3} \mathrm{~s}^{-1}$ at typical airspeeds $\left(120 \mathrm{~ms}^{-1}\right)$. The precision and lowest measurable concentration from the $1 \mathrm{~Hz} \mathrm{CDP}$ data is approximately $0.035 \mathrm{~cm}^{-3}$. Large water droplets and ice crystals were measured using a wing pylon mounted SPEC Inc., 2DS128 (referred to as 2DS) probe. The 2DS is a high volume 2-D Optical Array Probe (2D-OAPs, see Knollenberg, 1981, for further description). An overview of all the wing pylon mounted cloud probes is shown in Table 2. Details of data processing techniques used with the 2DS probe can be found in Appendix B.

\subsection{Remote sensing instrumentation}

A $3 \mathrm{GHz}$ Doppler-Polarisation Radar (Chilbolton Advanced Meteorological Radar - CAMRa, Goddard et al., 1994) at CFARR performed RHI scans along the $253^{\circ}$ radial, while a $35 \mathrm{GHz}$ cloud Radar at CFARR pointed vertically. Due to

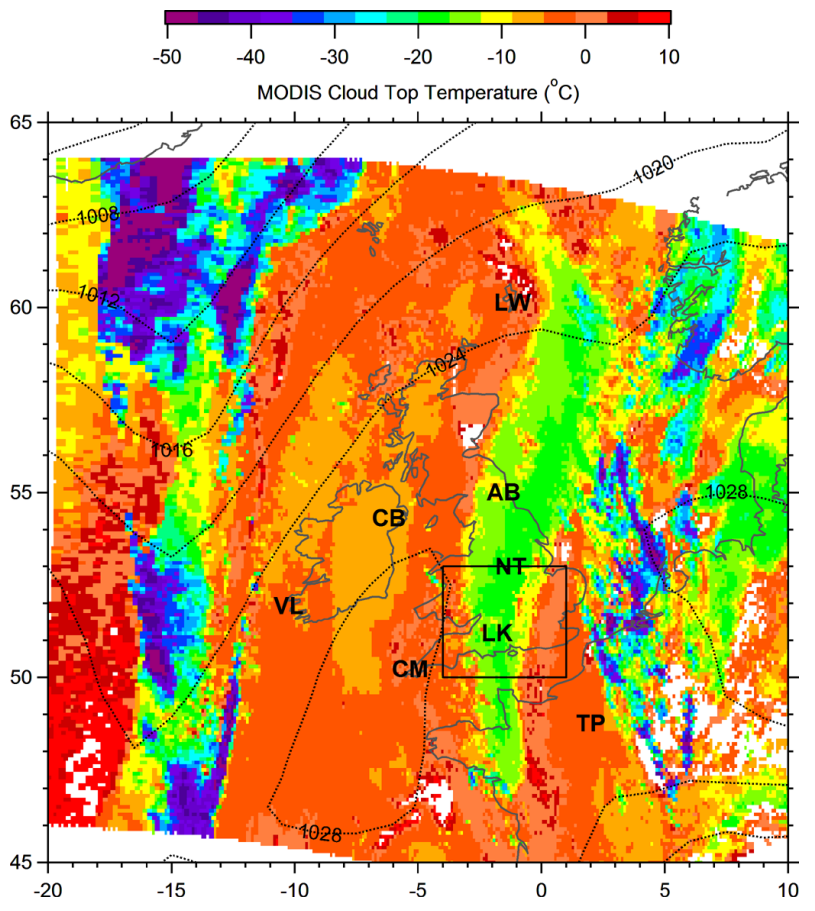

Fig. 2. Colour plot of MODIS derived cloud top temperature from the 11:20 UTC Terra overpass on 18 February 2009. Data have been remapped onto a $0.1^{\circ}$ cartesian grid using nearest neighbour values. Surface pressure contours ( $4 \mathrm{mBar}$ intervals) from the ECMWF interim reanalysis dataset are shown in black dashed lines.

the relatively low frequency at which the CAMRa operates, it mainly detects precipitation sized particles. The Doppler capability allows the radial velocity of the Radar targets in the moving airmass to be determined. The $35 \mathrm{GHz}$ cloud radar is sensitive to both precipitation sized particles and also cloud droplets in low level liquid clouds. A Lidar ceilometer was also positioned at CFARR. The latter two instruments are described in Illingworth et al. (2007).

\section{Meteorological conditions and radar data}

On the 18 February 2009 the UK was experiencing high pressure conditions resulting in large scale descent of relatively warm, dry air. The surface was influenced by an initially slow moving (to the west) and then (at the time of the flight) virtually stationary frontal system, which was composed of warm air to the west and cold air to the east. The frontal boundary was roughly aligned north-south. The majority of the UK was covered by cloud at this time.

Figure 2 shows the surface pressure field (ECMWF 12:00 UTC reanalysis) and MODIS derived cloud top temperature (11:20 UTC Terra overpass) for 18 February 2009. Surface pressure over the UK was over $1020 \mathrm{mBar}$ and isobars were distant resulting in low surface wind speeds. The MODIS data shows a large area of supercooled cloud over 
Table 1. Summary of constant altitude runs conducted by the FAAM BAe146 aircraft along a CFARR radial on 18 February 2009.

\begin{tabular}{lccccc}
\hline Reference & $\begin{array}{c}\text { Start Time } \\
\text { UTC }\end{array}$ & $\begin{array}{c}\text { End Time } \\
\text { UTC }\end{array}$ & $\begin{array}{c}\text { Heading }^{\mathrm{a}} \\
{ }^{\circ}\end{array}$ & $\begin{array}{c}\text { Altitude }^{\mathrm{b}} \\
\mathrm{km}\end{array}$ & $\begin{array}{c}\text { Temperature }^{\mathrm{c}} \\
{ }^{\circ} \mathrm{C}\end{array}$ \\
\hline R1 & $11: 57: 00$ & $12: 12: 04$ & 101 & 4.08 & -9.2 \\
R2 & $12: 13: 52$ & $12: 25: 12$ & 255 & 3.48 & -11.7 \\
R3 & $12: 25: 26$ & $12: 44: 35$ & 96 & 3.18 & -9.3 \\
R4 & $12: 45: 55$ & $12: 58: 13$ & 255 & 2.88 & -6.9 \\
R5 & $13: 00: 04$ & $13: 18: 55$ & 95 & 2.57 & -4.3 \\
R6 & $13: 20: 23$ & $13: 32: 57$ & 255 & 2.27 & -2.1 \\
R7 & $13: 34: 27$ & $13: 54: 02$ & 90 & 1.97 & -0.2 \\
\hline
\end{tabular}

${ }^{\text {a Approximate value }}$

${ }^{\mathrm{b}}$ Mean value from the GPS receiver

${ }^{\mathrm{c}}$ Mean value from the de-iced Rosemount sensor

Table 2. Wing pylon mounted cloud probes on the FAAM BAe146 aircraft on 18 February 2009.

\begin{tabular}{lcccccc}
\hline Name & Technique & $\begin{array}{c}D_{\min } \\
(\mu \mathrm{m})\end{array}$ & $\begin{array}{c}D_{\max } \\
(\mu \mathrm{m})\end{array}$ & $\begin{array}{c}\text { Pixel/Bin } \\
\text { Width }(\mu \mathrm{m})\end{array}$ & Num Bins & GrayScale \\
\hline FSSP/SPP-200 & FS & 2 & 50 & Variable & 30 & n/a \\
$\mathrm{CDP}^{\mathrm{b}}$ & FS & 2 & 50 & Variable & 30 & n/a \\
$\mathrm{CIP}^{\mathrm{a}} 100^{\mathrm{c}}$ & OAP & 100 & 6200 & 100 & 62 & $1-\mathrm{bit}$ \\
$2 \mathrm{DS}-128^{\mathrm{d}}$ & OAP & 10 & 1260 & 10 & 126 & $1-\mathrm{bit}$ \\
\hline
\end{tabular}

Probes are described in detail in ${ }^{\mathrm{a}}$ Knollenberg (1981), ${ }^{\mathrm{b}}$ McFarquhar et al. (2007), ${ }^{\mathrm{c}}$ Baumgardner et al. (2001), and ${ }^{\mathrm{d}}$ Lawson et al. (2006) .

the UK in the region influenced by the warm front (cloud top temperature approximately $-12^{\circ} \mathrm{C}$ ). The MODIS data also show cloud to the east and west of the mid-level band of cloud (cloud top just below freezing in Fig. 2). Low level liquid water clouds were also observed overhead CFARR by the Lidar ceilometer (Fig. 4).

Profiles of temperature and dew point from radiosonde ascents from various stations at 12:00 UTC are shown in Fig. 3. The majority of the radiosonde profiles in the region show evidence of a saturated layer at altitudes below $2 \mathrm{~km}$ (around $\left.-2{ }^{\circ} \mathrm{C}\right)$. Profiles from stations LK ( $<30 \mathrm{~km}$ west of CFARR), NT and AB also showed evidence of another saturated layer at approximately $3.6 \mathrm{~km}$ altitude $\left(-12^{\circ} \mathrm{C}\right)$ which extended only a few $100 \mathrm{~m}$ in the vertical. All stations show warm dry air aloft, which is consistent with large scale descent during high surface pressure conditions. Saturated layers were capped by temperature inversions (varying between 1 and $7^{\circ} \mathrm{C}$ ).

Also shown in Fig. 3 are in-situ data from the BAe146 aircraft taken during a profile ascent (11:42-11:57 UTC) in the region of CFARR. This shows a saturated layer (400 m vertical extent) with cloud top and cloud base temperatures of $-12.2^{\circ} \mathrm{C}$ and $-10.0^{\circ} \mathrm{C}$, respectively. This layer was found at around $3.5 \mathrm{~km}$ altitude, and was overlying a thicker layer of warm cloud (cloud top $<2 \mathrm{~km}$ altitude) which approached the surface. The lower level cloud ( $<2 \mathrm{~km}$ altitude) is not studied in this paper. The upper level cloud was capped by a temperature inversion $\left(\sim 5^{\circ} \mathrm{C}\right.$ in magnitude) and dry air (dew point $\left.\sim-30^{\circ} \mathrm{C}\right)$. The in-situ measurements of cloud top temperatures are in agreement with both radiosonde and MODIS data. All three data sources confirm the presence of an extensive layer of supercooled mid-level stratus cloud over the UK.

The $35 \mathrm{GHz}$ vertical pointing Radar at the CFARR ground site measured returns from the two saturated layers (identified in the sonde ascents above) for over $24 \mathrm{~h}$, starting at $\sim 06: 00$ UTC. The time series of radar reflectivity during the flight period is shown in Fig. 4. Echos from the mixed-phase layer are dominated by the large ice particles present and values of $-5 \mathrm{dBZ}$ were measured both in the supercooled layer, and in the glaciated virga below. Key features are annotated on the plot. Also shown in Fig. 4 is the time series from the Lidar ceilometer. Lidar is very sensitive to liquid water clouds, and strong reflections (red colours: note the logarithmic colour scale) were recorded from low level liquid water layers at $600 \mathrm{~m}, 800 \mathrm{~m}$ and $1200 \mathrm{~m}$. These layers were optically thick, and prevented further penetration of the Lidar beam to the higher cloud layers.

The ice particles falling from the supercooled layer are observed to evaporate at $2.5 \mathrm{~km}$; however some streaks appeared to survive to lower levels, influencing the low level water clouds. Appreciable drizzle was observed at low levels during this period in both the radar and Lidar observations (up to $+5 \mathrm{dBZ}$ at 14:00 UTC). 

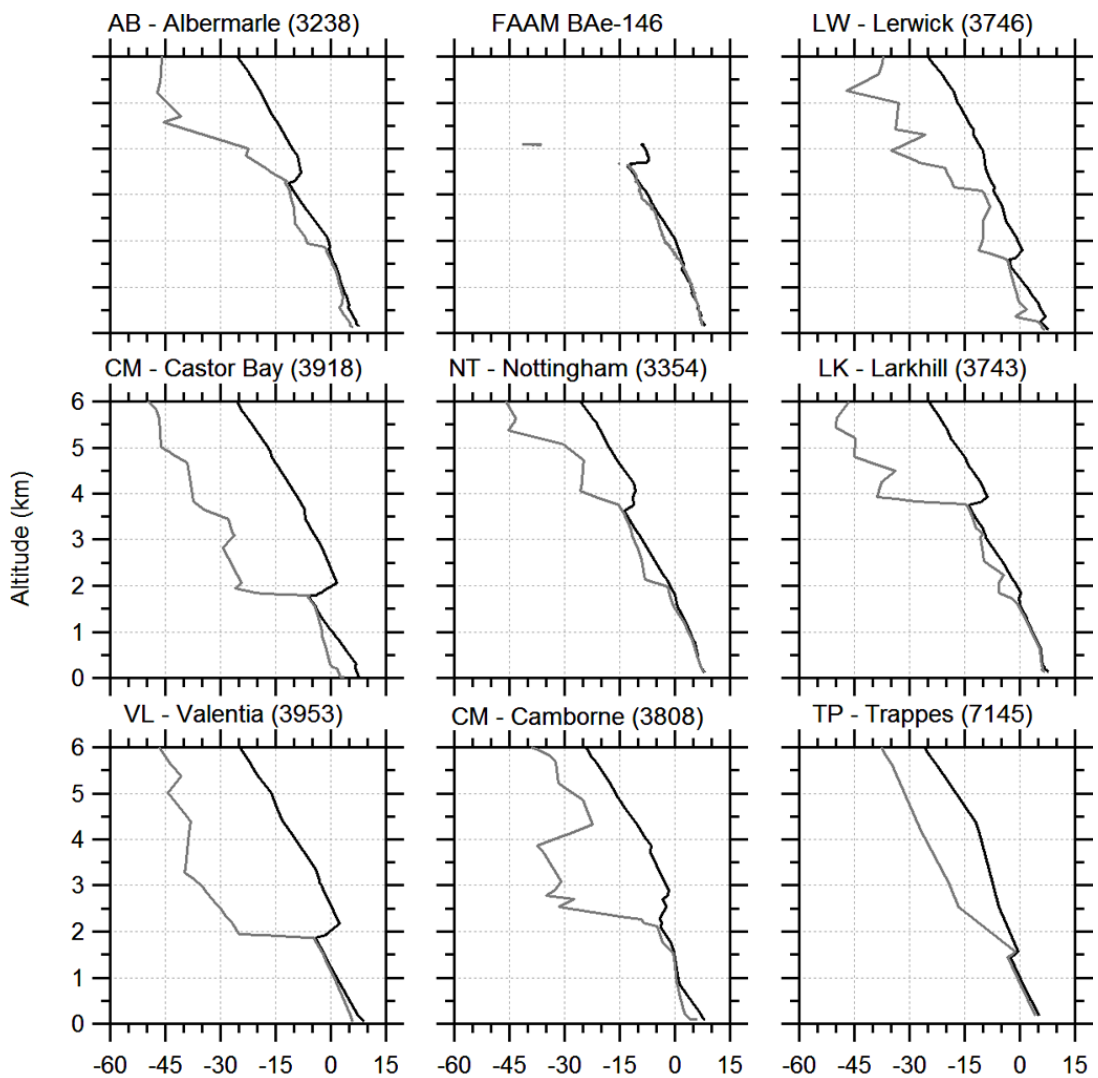

LK - Larkhill (3743)
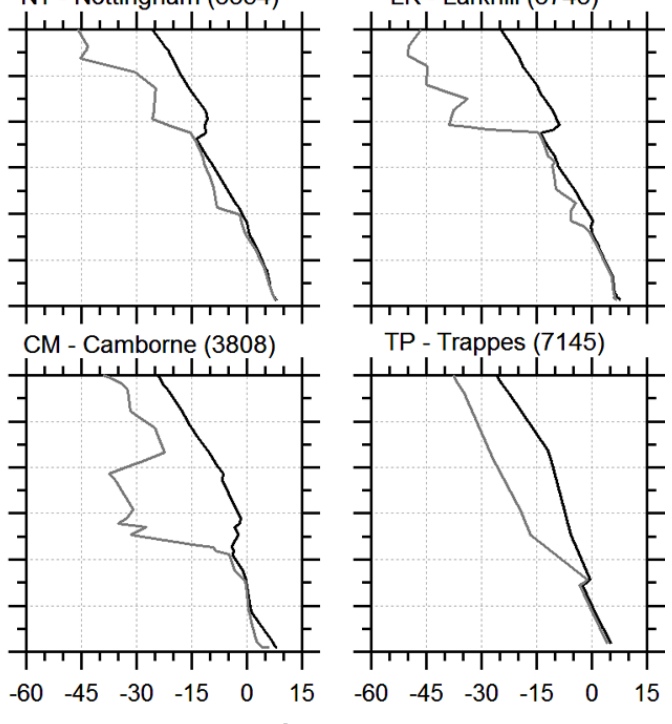

TP - Trappes (7145)

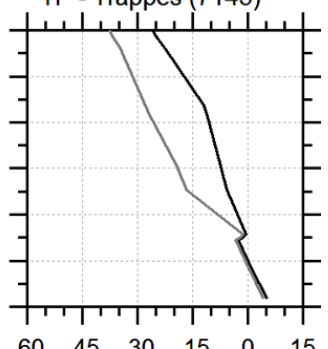

Temperature / Dewpoint $\left({ }^{\circ} \mathrm{C}\right)$

Fig. 3. Profiles of temperature (black) and dewpoint (grey) from radiosonde station soundings at 12:00 UTC and the FAAM aircraft profile (11:42-11:57 UTC). Radiosonde station locations are highlighted in Fig. 2.
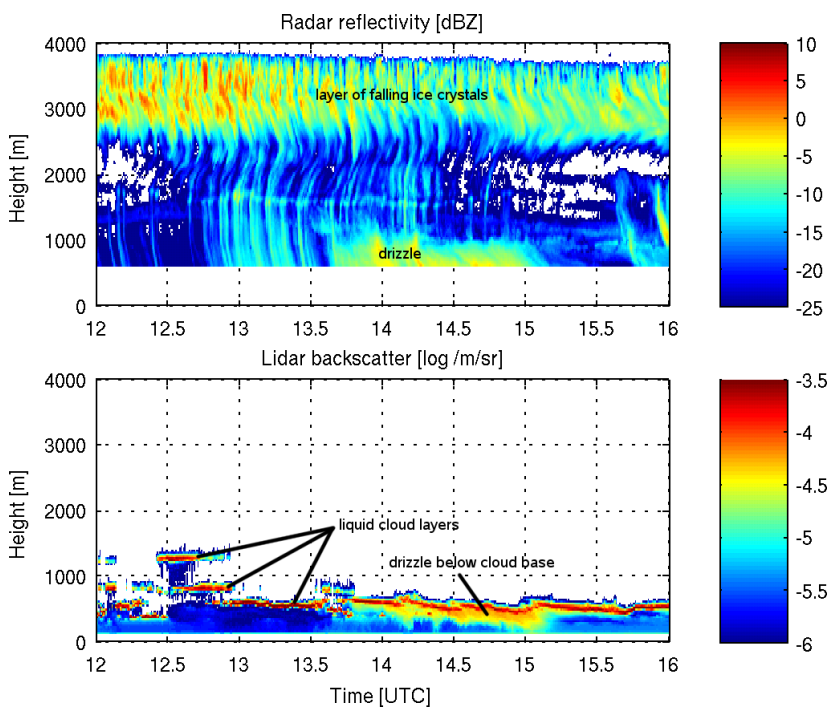

Fig. 4. Time series of vertically pointing cloud Radar and Lidar ceilometer measurements during the flight. Key features are annotated for reference.
RHI scans from the $3 \mathrm{GHz}$ CAMRa along the $253^{\circ}$ radial are shown for runs R2-R5 in Figs. 5-8. The CAMRa recorded reflectivities of around $-5 \mathrm{dBZ}$ in/below the supercooled stratus cloud, as observed overhead. These scans also show regions of enhanced reflectivity (0-20 dBZ) from cloud top to the surface at distances of around $20 \mathrm{~km}$ from CFARR, and are associated with a region of localised convection. Due to the stationary nature of the enhanced reflectivity/convective feature, the system can be considered to be in steady state. The local convection was also identified on the Met Office operational Radar network and consisted of a band of enhanced reflectivity orientated approximately north-south $\sim 20 \mathrm{~km}$ to the west of CFARR.

Figure 9 shows an RHI scan from CAMRa focussing on the region of convective activity, showing a cross section taken approximately perpendicular to the line of showers (azimuth $=265^{\circ}$ ). The radar reflectivity is shown in panel (a): as before values in the range -10 to $0 \mathrm{dBZ}$ are observed in the layer of ice crystals falling from the supercooled liquid at cloud top. Much larger reflectivities (up to $+20 \mathrm{dBZ}$ ) are observed in the region around $20 \mathrm{~km}$ west of CFARR, corresponding to the embedded convective feature, and are likely dominated by rimed crystals 
and graupel particles (also observed in the aircraft imagery: Fig. $11 \mathrm{~b}$ and c). Reflectivities below the melting layer (1.4 km height approximately) peak just below $+30 \mathrm{dBZ}$, suggesting a peak rainrate of around $2 \mathrm{~mm} \mathrm{~h}^{-1}$ (Marshall and Palmer, 1948).

Figure $9 \mathrm{~b}$ shows the Doppler velocity field: Superimposed on this plot are arrows highlighting the motion of the airmasses (perpendicular to the line of showers). Convergence of weak easterly (warm colours) and westerly winds (cold colours) leads to air being lifted around $1-2 \mathrm{~km}$ in height to cloud top, where the updraught is capped by the strong inversion (cf. Fig. 3) and spreads out horizontally. Note therefore that the air in this convective feature is entrained from the ice-saturated air at $2-3 \mathrm{~km}$ height, and not from the boundary layer. Since the flow producing this updraught is quasi-two dimensional, the Doppler measurements can be used to infer the vertical velocity field $w$, by integration of the continuity equation. Assuming $w=0$ at cloud top (because of the inversion) Fig. 9c shows the calculated values of $w$ (zoomed in on the region of convergence). A clear up/down-draught structure is observed: The peak updraught was estimated to be $1.5 \mathrm{~m} \mathrm{~s}^{-1}$. Note the sensitivity of the derived velocities to the fall velocity of the ice particles is weak at this range: Correcting the Doppler velocities for a particle fall-speed of $2 \mathrm{~ms}^{-1}$ only changed the derived vertical velocities by $10 \%$.

\section{Cloud properties}

The FAAM aircraft conducted a series of constant altitude runs along the $253^{\circ}$ radial from the CFARR ground site as summarised in Table 1. The first of these runs (R1) was performed above the supercooled cloud (altitude $=4.08 \mathrm{~km}$, temperature $=-9.2^{\circ} \mathrm{C}$ ) to characterise any possible ice seeding from above. During R1 none of the cloud probes detected any particles within their respective size ranges; this was confirmed by the radar time series (Fig. 4), ruling out the possibility of ice seeding from above. This is not surprising as the air above the cloud was found to be warm and dry due to the large-scale descent associated with the high pressure system. Measured cloud droplet number/mass concentrations from the CDP, as well as round and irregular particle number/mass concentrations from the 2DS, are shown as a function of distance from CFARR along the $253^{\circ}$ radial for runs R2-R5 in Figs. 5-8, respectively. Also shown in Figs. 5-8 is the Radar reflectivity from RHI scans performed half way through the aircraft constant altitude run. The measured insitu cloud microphysical properties are binned at $1 \mathrm{~Hz}$ time resolution which corresponds to approximately $120 \mathrm{~m}$ spatial resolution. Number concentrations of cloud particles from the CDP and 2DS probe gathered during runs R2-R5 are also shown in Fig. 10. The data in these plots are separated into data at different temperature levels and geographical locations. Based on the CAMRa RHIs, the region of convective activity is defined here as being $15-25 \mathrm{~km}$ horizontal distance from CFARR, whereas data from cloud unaffected by this convection is defined as being $25-100 \mathrm{~km}$ horizontal distance from CFARR.

Run R2 (Fig. 5) was performed inside the supercooled stratus cloud $\left(3.48 \mathrm{~km},-11.7^{\circ} \mathrm{C}\right)$. The droplet concentration from the CDP was around $50 \mathrm{~cm}^{-3}$ for the majority of R2 (west of $45 \mathrm{~km}$ ). Cloud droplet number/mass concentrations dropped to around zero at distances $<40 \mathrm{~km}$ from CFARR. This was a result of a slight increase in cloud base altitude. The measured cloud droplet water concentration from the CDP along R2 peaked at $0.5 \mathrm{~g} \mathrm{~m}^{-3}$. At around $50 \mathrm{~km}$ distance from CFARR the 2DS data suggest there was an area of cloud with enhanced concentrations of large cloud droplets/drizzle droplets (up to $20 \mathrm{~L}^{-1}$ ). This is confirmed by the other probes including the CPI and Hotwire LWC sensor. Throughout the cloud a small number of ice crystals were found along the entire straight and level run, with concentrations of around $2 \mathrm{~L}^{-1}$ common, contributing around $0.01 \mathrm{~g} \mathrm{~m}^{-3}$ to the total cloud water content. These crystals were a combination of stellar and plate like habits. Images of particles which were classified as ice crystals from the 2DS along R2 are shown in Fig. 11a. These data were gathered over a distance of $\sim 5 \mathrm{~km}$ in the horizontal, between 32 and $37 \mathrm{~km}$ from CFARR. A composite average particle size distribution from the CDP and 2DS probes along R2 is shown in Fig. 12a. Also shown in the plot is the size distribution from particles measured by the 2DS which are too small for shape analysis based on a pixel threshold of 16 . Number concentrations are consistent in the overlap region between different probes.

Run R3 (Fig. 6) was performed below the supercooled layer cloud $\left(3.18 \mathrm{~km},-9.3^{\circ} \mathrm{C}\right)$ and included a short penetration of the convective feature located $20 \mathrm{~km}$ west of CFARR. During this flight turbulence data from a 5-hole pressure port probe was unreliable due to ice build up on the probe in the mixed phase conditions. Therefore it was not possible to measure the updraft velocity within the convective feature. In this case the aircraft vertical acceleration determined from the 3-D accelerometers was used as a measure of turbulence levels. The vertical acceleration was shown to be significantly perturbed during transit through the boundaries of the convective feature. The CDP derived cloud droplet number concentration was approximately zero throughout the majority of the run. Ice crystal concentrations measured by the 2DS were relatively low (approximately $0.1 \mathrm{~L}^{-1}$ ) below the supercooled cloud. There was an area (approximately $20 \mathrm{~km}$ horizontal distance from CFARR) where the CDP cloud droplet concentration increased to over $50 \mathrm{~cm}^{-3}$. This was in the convective feature characterised by high reflectivity as seen by the CAMRa. In this region the ice crystal and large droplet number concentration measured by the 2DS also greatly increases to over $20 \mathrm{~L}^{-1}$ and $40 \mathrm{~L}^{-1}$, respectively. The mass concentration of the ice in this region is over $0.1 \mathrm{~g} \mathrm{~m}^{-3}$ whereas the large drops/drizzle mass only increases to around $0.005 \mathrm{~g} \mathrm{~m}^{-3}$ which suggests that 


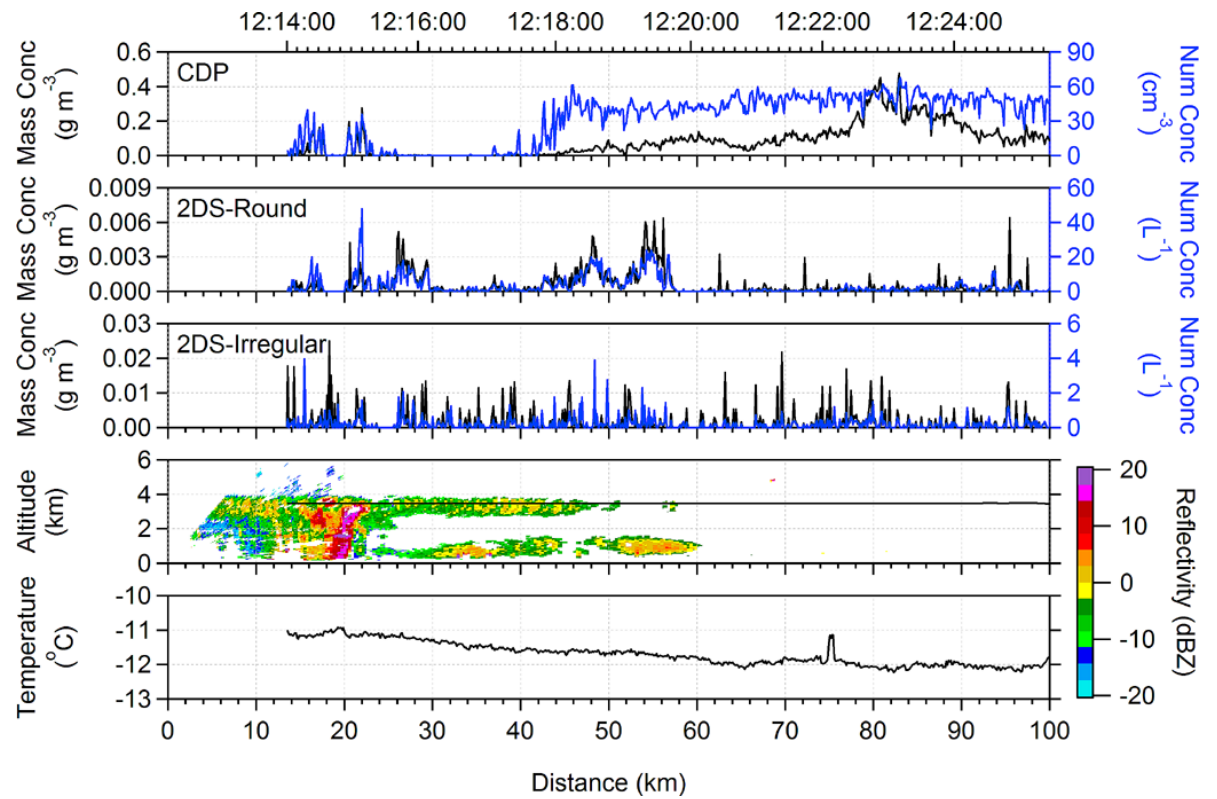

Fig. 5. Total particle mass (left axes, black lines) and number (right axes, blue lines) from the CDP and 2DS as a function of distance/time from CFARR. Data from the 2DS are separated into round and irregular categories. In-situ temperature from the de-iced Rosemount sensor is also shown. Data are from the BAe146 aircraft along the $253^{\circ}$ radial during constant altitude run R2. Also shown is the reflectivity from the $3 \mathrm{GHz}$ CAMRa RHI scan (12:19:29-12:21:29 UTC) along the $253^{\circ}$ radial.

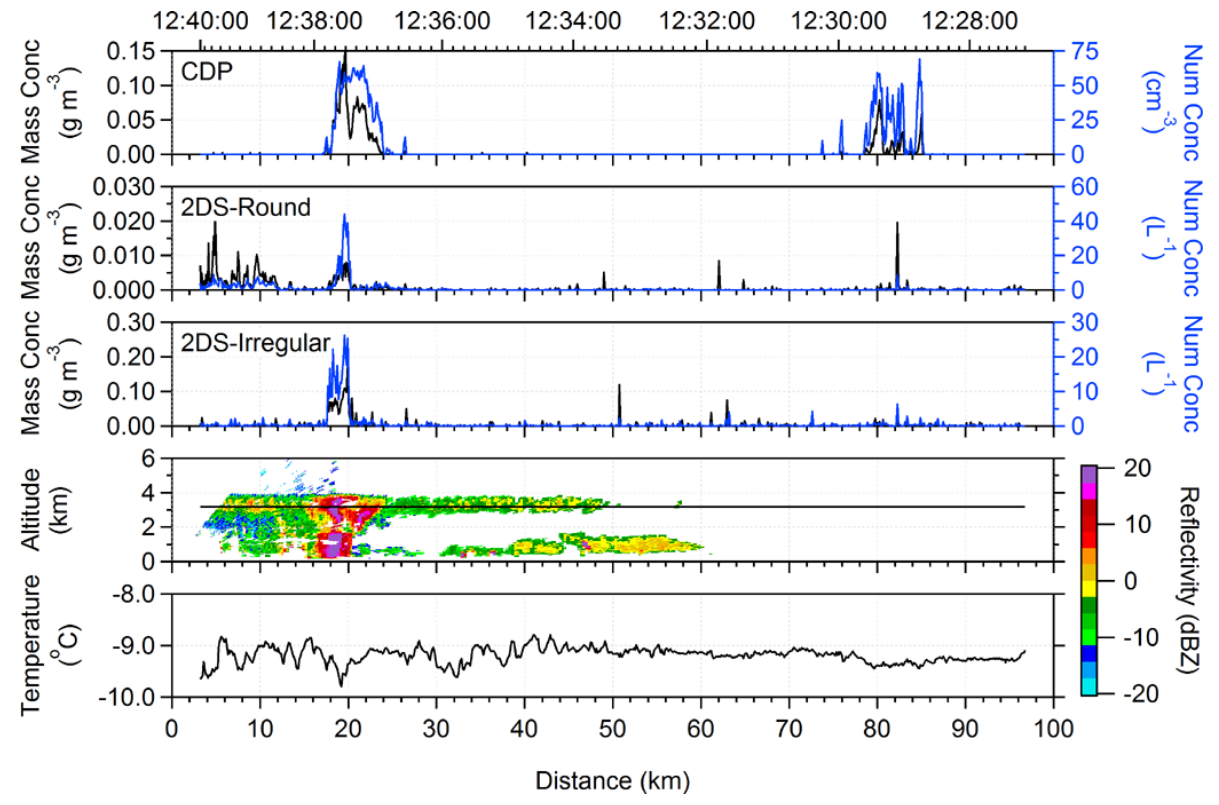

Fig. 6. Same as Fig. 5, except for run R3. The CAMRa RHI scan shown was from (12:32:22-12:34:22 UTC).

the ice crystals were much larger than the largest drops seen in the feature. Images of particles classified as ice in the convective feature are shown in Fig. 11b and are present as heavily rimed crystals, some of which may be heavily rimed columns. These images were collected over a horizontal distance of around $0.1 \mathrm{~km}$, at $\sim 19.8 \mathrm{~km}$ horizontal distance from CFARR. The ice particles (precipitation) below the supercooled cloud outside the convective feature (distances $>25 \mathrm{~km}$ ) were similar to those found in the supercooled cloud as shown in Fig. 11a.

Data from runs R4 $\left(2.88 \mathrm{~km},-6.9^{\circ} \mathrm{C}\right)$ and $\mathrm{R} 5(2.57 \mathrm{~km}$, $-4.3^{\circ} \mathrm{C}$ ) are shown in Figs. 7 and 8 . Both runs were performed below the supercooled layer cloud and briefly passed through the convective feature located $20 \mathrm{~km}$ west of 


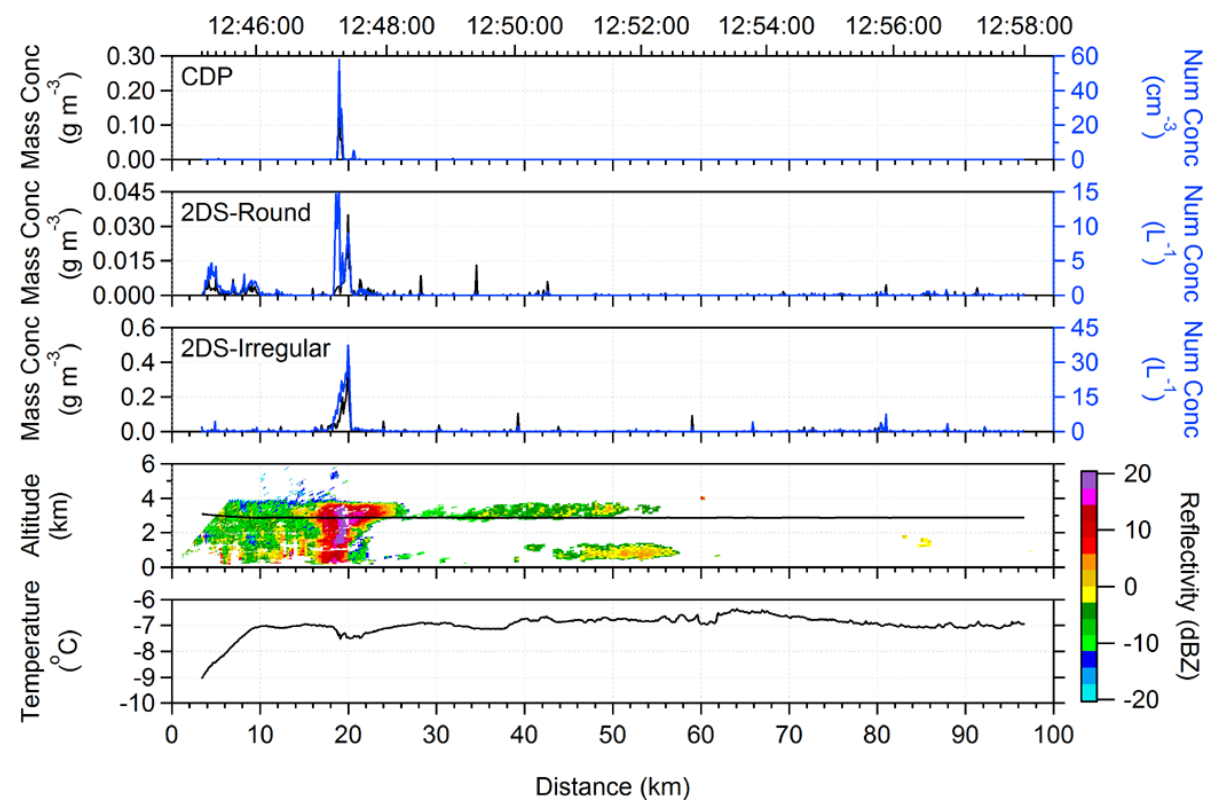

Fig. 7. Same as Fig. 5, except for run R4. The CAMRa RHI scan shown is from (12:51:12-12:53:12 UTC).

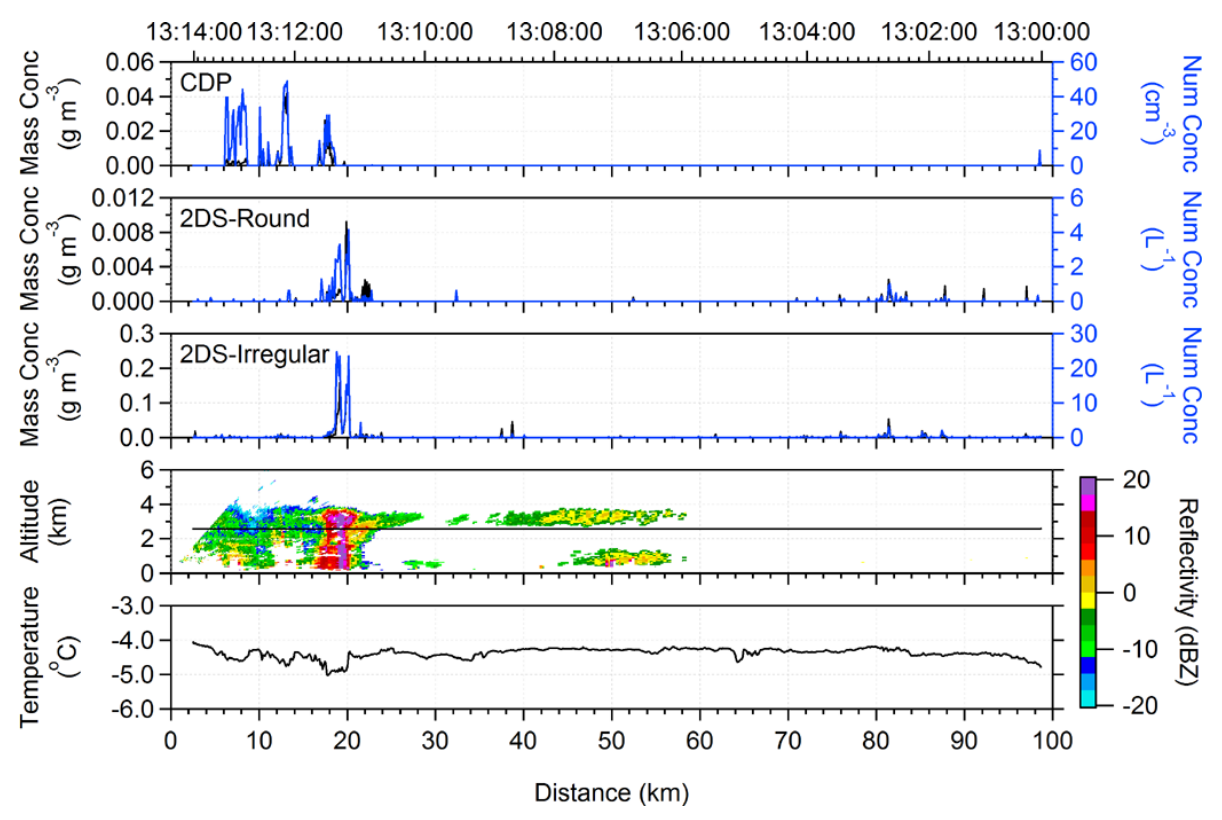

Fig. 8. Same as Fig. 5, except for run R5. The CAMRa RHI scan shown is from (13:08:12-13:10:12 UTC).

CFARR. Both of these runs have similar characteristics to the previous run (R3), namely small concentrations of ice crystals below the supercooled cloud, with enhanced concentrations of ice and large cloud droplet concentrations in/around the convective region. Ice particle number concentrations from the 2DS peak at over $20 \mathrm{~L}^{-1}$ during both passes through the convective feature. Ice and drop/drizzle mass from the 2DS peak at around $0.2 \mathrm{~g} \mathrm{~m}^{-3}$ and $0.008 \mathrm{~g} \mathrm{~m}^{-3}$ in the convective region, respectively. Images of ice crystals from the
2DS in the convective cloud along runs R4 and R5 are shown in Fig. 11c and d, respectively. These images were obtained along an $\sim 0.2 \mathrm{~km}$ horizontal section in regions of high cloud droplet concentrations as measured by the CDP, and therefore most likely updrafts. They show marked differences from each other and those seen in the convective cloud at lower temperatures (Fig. 11b) and in/beneath the supercooled layer cloud (Fig. 11a). The ice crystals in R4 appear to be lightly rimed columns typically around $500 \mu \mathrm{m}$ in length, 

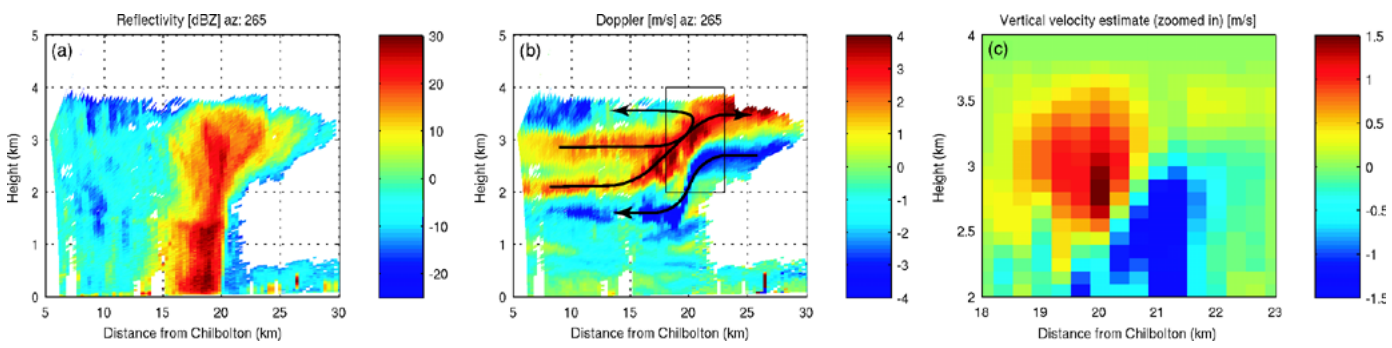

Fig. 9. RHI scan perpendicular to line of showers. Panel (a) shows radar reflectivity; (b) is Doppler velocity. Arrows indicating the air motion responsible for the convergence have been overlayed on panel (b). Panel (c) shows a zoomed-in view of vertical velocity in the region of convergence (boxed area in panel b), derived from integration of the 2-D continuity equation using the Doppler winds.
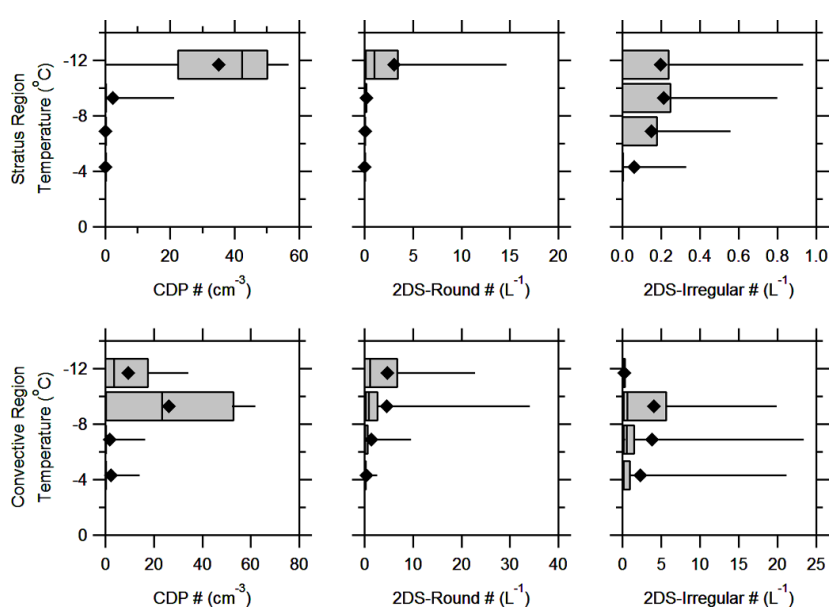

Fig. 10. Number concentration of round particles recorded by the 2DS probe from runs R2-R5. Whiskers extend to 5th and 95th percentiles, boxes encompass 25 th to 75 th percentiles and 50th percentiles are vertical lines. Mean values are represented by black markers. The convective region is defined as being $15-25 \mathrm{~km}$ distance from CFARR, whereas the stratus region is defined as being 25-100 km from CFARR.

whereas at the lower altitude/warmer temperature the ice crystals in R5 appear to be a mixture of smaller columns and hollow columns generally around $200 \mu \mathrm{m}$ or less in length, with no evidence of riming. Runs R3 and R4 also contained a significant number of large ( $>1 \mathrm{~mm}$ or more) graupel or heavily rimed ice particles, as well as liquid water droplets in/around the convective region of the cloud. The different types of cloud particle are not uniformly mixed horizontally across the convective region, but appear in discrete pockets due to the presence of the up/down-draughts.

The vertical profile of the number concentration of round drizzle/droplets and irregularly shaped (most likely ice) particles from the 2DS probe from constant altitude runs R2-R5 are shown in Fig. 10. Also shown are the number concentrations of droplets from the CDP. The plot contains statistical information on the 5 th, 25 th, 50th, 75th and 95 th percentiles as well as the mean of number concentrations. In the region of convective activity, cloud droplet concentrations measured below the supercooled layer cloud are highly variable, with peak values of the same order as values found in the supercooled layer cloud itself. Away from this region of convective activity, cloud droplet concentrations are very low below the layer cloud. Ice crystal number concentrations below the layer cloud are around 20 times larger in the convective region than away from it (up to $20 \mathrm{~L}^{-1}$ compared to $1 \mathrm{~L}^{-1}$ ). No drizzle was found below the layer cloud away from the convective region, despite being observed at $50 \mathrm{~km}$ distance within the layer cloud during R2. Large drops/drizzle particles (from the 2DS) were measured in the convective region in/below the layer cloud.

Average ice particle size distributions in the convective region (15-25 km distance from CFARR) for runs R3-R5, conditionally averaged for cloud droplet number concentrations greater/less than $1 \mathrm{~cm}^{-3}$, are shown in Figs. 12b/c respectively. Conditional sampling by droplet number concentrations is undertaken to identify regions of updraft. The sampling is performed on the $1 \mathrm{~Hz}$ data representing averaging over spatial scales of about $120 \mathrm{~m}$. It is possible that regions of updraft may contain only low concentrations of cloud droplets after ice develops as the majority of droplets are removed by the Bergeron-Findeison or accretion processes. This could result in some regions of updraft which contain very low droplet concentrations being identified as regions of downdraft. In order to make this very unlikely a threshold of particle concentration of $1 \mathrm{~cm}^{-3}$ is used to separate updraft from downdraft/quiescent regions. This value was chosen as it is much smaller than likely droplet concentrations measured in the cloud and much larger than realistic concentrations of ice crystals likely to occur (or be observed) in the cloud. The sizing metric used in these plots is the diameter of a circle which would have the same total area as the original particle. This is done because column particles of the same size could have a variety of across/along array measured lengths depending on orientation upon sampling.

The ice particle size distribution at the lowest altitude/warmest temperature $\left(-4.3^{\circ} \mathrm{C}\right)$ is dominated by small $(<300 \mu \mathrm{m})$ particles in regions of high cloud droplets (Figure $12 \mathrm{~b})$ and thus updrafts. These ice particles are those which 


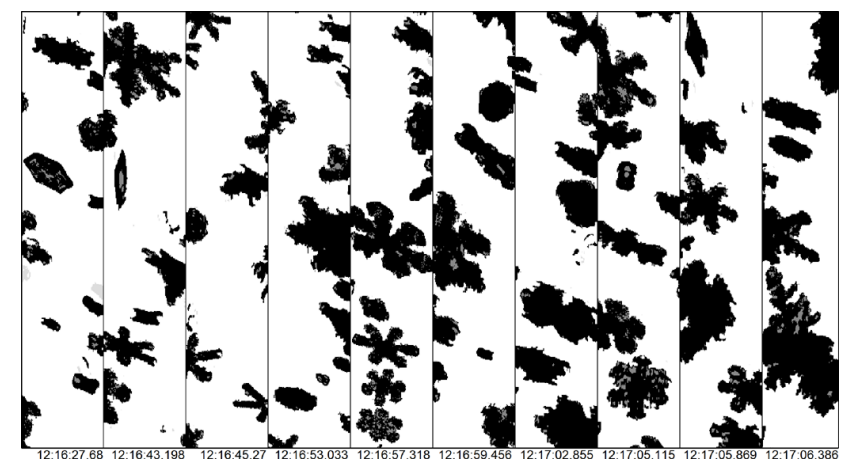

Fig. 11a. Particle images from the 2DS probe. Each image strip is approximately $1.28 \mathrm{~mm}$ wide and $12.8 \mathrm{~mm}$ long. Data are from $\mathrm{R} 2\left(T=-11.7^{\circ} \mathrm{C}\right.$, altitude $\left.=3.48 \mathrm{~km}\right)$ in the supercooled layer cloud above CFARR.

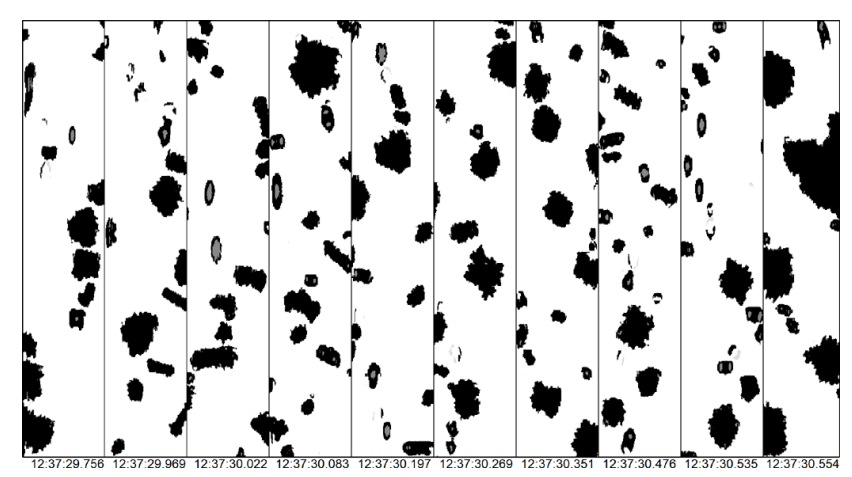

Fig. 11b. As Fig. 11a. Data are from $\mathrm{R} 3\left(T=-9.3^{\circ} \mathrm{C}\right.$, altitude $=3.18 \mathrm{~km}$ ) in the region of convective cloud encountered approximately $20 \mathrm{~km}$ west of CFARR.

have been generated by Secondary Ice Production. The particle size distribution in low cloud droplet number concentration regions at the same altitude/temperature is instead dominated by larger particles extending to over $1 \mathrm{~mm}$ in size (12c). These are rimed particles which are most likely falling out of the convective system. At colder temperatures $\left(-6.9^{\circ} \mathrm{C}\right.$ and $-9.3^{\circ} \mathrm{C}$ ), the high droplet concentration regions have a significant contribution of ice particles $>300 \mu \mathrm{m}$ to the total number concentration (Fig. 12b). This is in strong contrast to the $-4.3^{\circ} \mathrm{C}$ distribution which only contains the smaller particles, and is due to the growth of the columns seen at lower altitudes in the updraft as they are lifted. In the region of low droplet concentrations, large numbers of rimed particles (D $\sim 300 \mu \mathrm{m})$ are seen at the intermediate level $\left(-6.9^{\circ} \mathrm{C}\right)$ falling out of the system. Above this $\left(-9.3^{\circ} \mathrm{C}\right)$, little ice is detected in the low cloud droplet concentration region, presumably as most of the large precipitation has already fallen out.

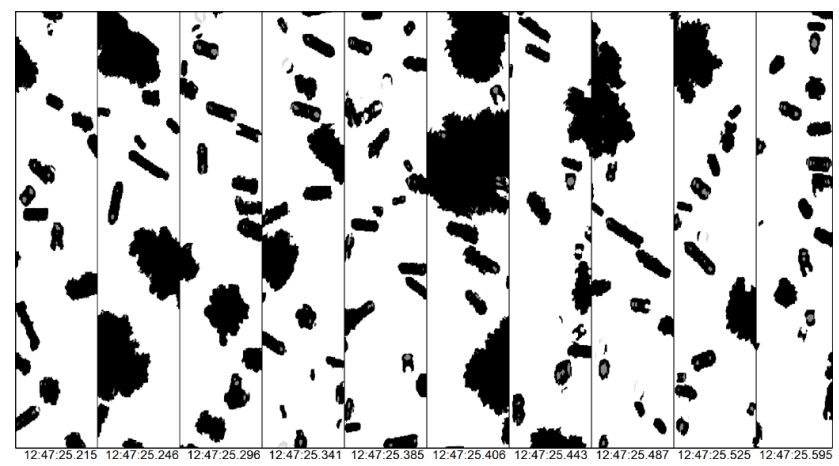

Fig. 11c. As Fig. 11a. Data are from $\mathrm{R} 4\left(T=-6.9^{\circ} \mathrm{C}\right.$, altitude $=2.88 \mathrm{~km}$ ) in the region of convective cloud encountered approximately $20 \mathrm{~km}$ west of CFARR.

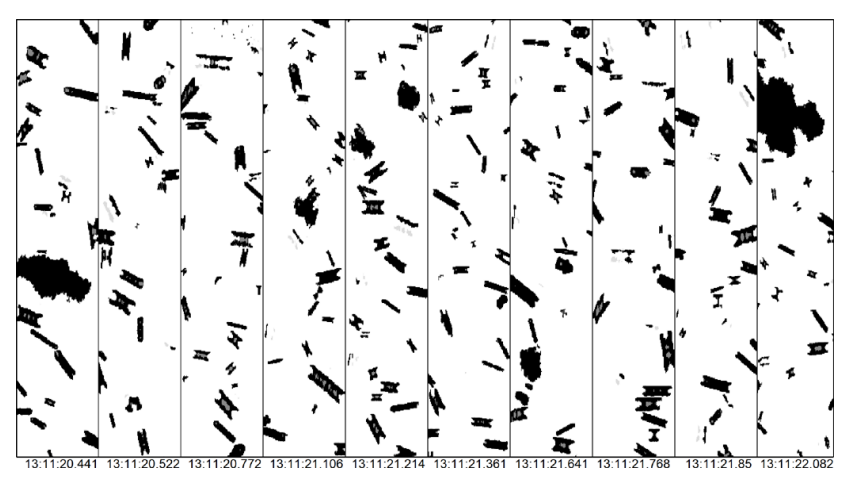

Fig. 11d. As Fig. 11a. Data are from R5 $\left(T=-4.3{ }^{\circ} \mathrm{C}\right.$, altitude $=2.57 \mathrm{~km}$ ) in the region of convective cloud encountered approximately $20 \mathrm{~km}$ west of CFARR.

\section{In-situ aerosol properties}

Composition of the submicron aerosol measured using the C-ToF-AMS during a profile ascent (11:42-11:57 UTC) in the region of CFARR is shown in Fig. 13. Also shown in Fig. 13 is the CDP measured cloud droplet number concentration. The CDP data are included on Fig. 13 to inform the reader when in-cloud conditions were encountered. No data from the C-ToF-AMS is shown in Fig. 13 during the profile ascent between $1-1.5 \mathrm{~km}$ altitude, as sampling was suspended to prevent instrument contamination with water. The C-ToF-AMS sampling was also suspended during runs R2R4 for the same reason. Poor transmission of large particles through rosemount inlets will mean that aerosol mass measured will mostly be from interstitial aerosols. Artefacts from droplet/crystal breakup on the rosemount cannot be ruled out but are of little consequence, as we are only concerned with the out of cloud aerosol. Aerosol composition at the lowest altitudes $(<0.4 \mathrm{~km})$ was dominated by ammonium nitrate and organic species. Above this $(0.4-3.3 \mathrm{~km})$ was a region where the aerosol consisted of a partly ammonium neutralised sulphate aerosol. Mixing between these layers 


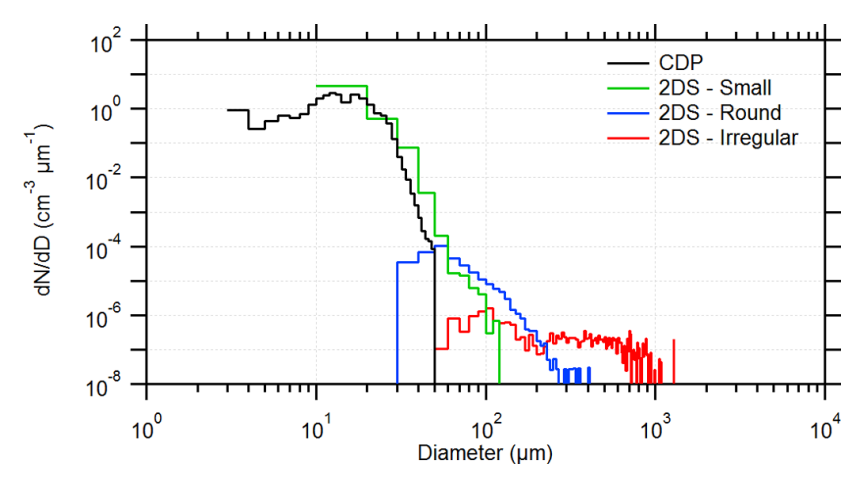

Fig. 12a. Average cloud particle size distribution from the FAAM aircraft. Data are from R2 in the supercooled layer cloud $\left(T=-11.7^{\circ} \mathrm{C}\right.$, altitude $\left.=3.48 \mathrm{~km}\right)$ observed above CFARR.

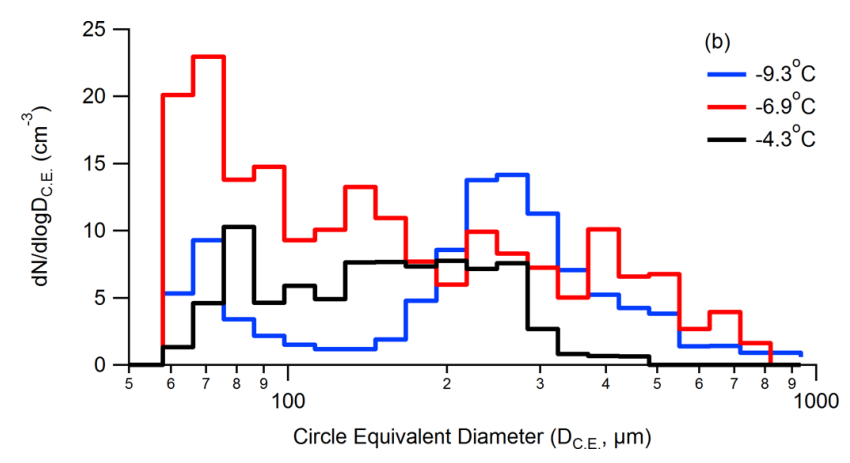

Fig. 12b. Ice particle size distribution from the 2D-S in the convective region $\left(15-25 \mathrm{~km}\right.$ distance from CFARR) in high $\left(>1 \mathrm{~cm}^{-3}\right)$ cloud droplet number concentration regions.

is limited due to the presence of a temperature inversion. Above the supercooled cloud, significant amounts of sulphate and organic mass were found in the submicron aerosol. Mean concentrations of sulphate, nitrate, ammonium and organic aerosol mass from the above cloud run (R1) are also shown in Fig. 13. The data from the above cloud run (R1) confirm the presence of sulphate and organic material in the aerosol particles (concentrations of the order of $0.1 \mu \mathrm{g} \mathrm{m}^{-3}$ ). Aerosol composition information was not obtained from the below cloud constant altitude runs. Quantification of dust and biological particle concentrations was not possible due to instrumentation limitations. Aerosol number concentrations $(0.1<$ Diameter $<3 \mu \mathrm{m})$ from the PCASP during runs R1 (above cloud) and R3 (below cloud) are shown in Fig. 14. Data plotted are 5th, 25th, 50th, 75th and 95th percentiles, as well as means as diamond markers. Data from below cloud were taken from a subset of the run due to the presence of cloud and precipitation. PCASP data were additionally filtered to remove contamination from precipitation shattering on the inlet by removing any data with $1 \mathrm{~s}$ total volume concentrations exceeding $0.1 \mu \mathrm{m}^{3} \mathrm{~cm}^{-3}$, which occurred in short infrequent pulses. The PCASP data in Fig. 14 show particle concentrations of around $25 \mathrm{~cm}^{-3}$ above and below the layer

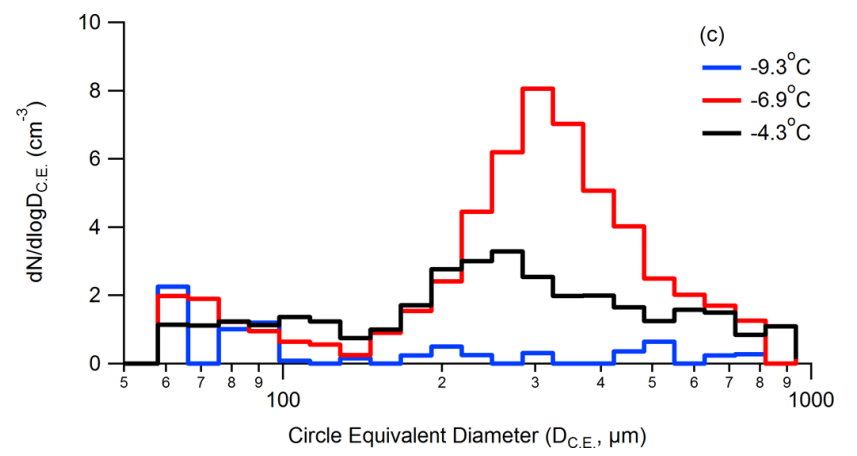

Fig. 12c. Ice particle size distribution from the $2 \mathrm{D}-\mathrm{S}$ in the convective region $\left(15-25 \mathrm{~km}\right.$ distance from CFARR) in low $\left(<1 \mathrm{~cm}^{-3}\right)$ cloud droplet number concentration regions.

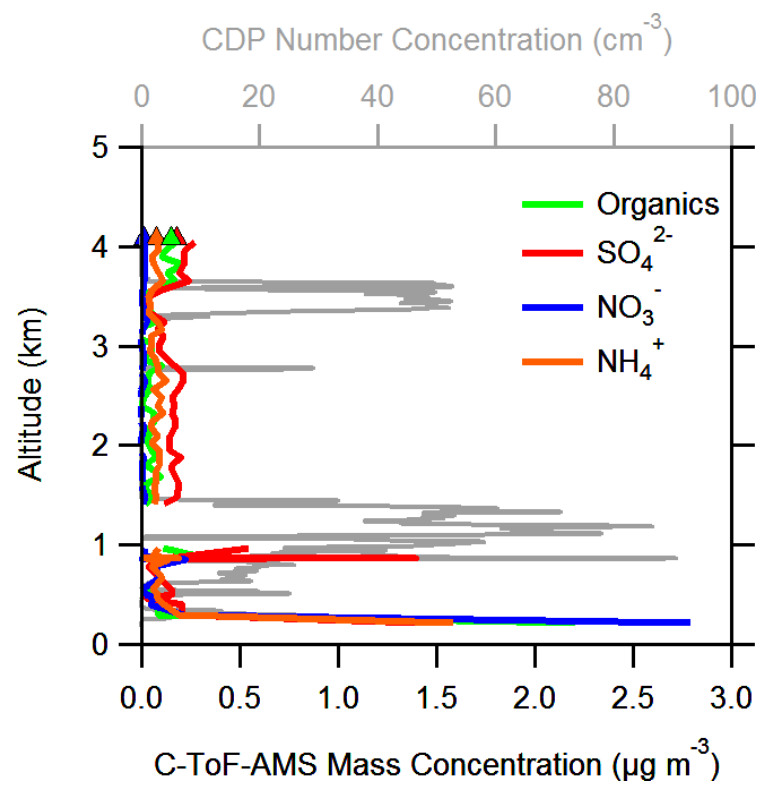

Fig. 13. Vertical profile of mass concentration for submicron aerosol species from the C-ToF-AMS. Cloud droplet number concentrations (measured by the $\mathrm{CDP}$ ) are also shown on the top axis.

cloud. Measurements of trace gases did not show any measureable evidence of transport of boundary layer air upwards in the convective region into the layer cloud aloft. This is consistent with the evidence from the Doppler radar observations in Fig. 9.

\section{Discussion and conclusions}

In-situ observations of cloud microphysical properties show that small concentrations of ice particles were formed in a slightly supercooled stratus cloud (cloud top and cloud base temperatures -12.2 and $-10.0^{\circ} \mathrm{C}$, respectively) during winter over the UK. These measurements are in broad agreement with Lidar observations of lightly precipitating slightly 


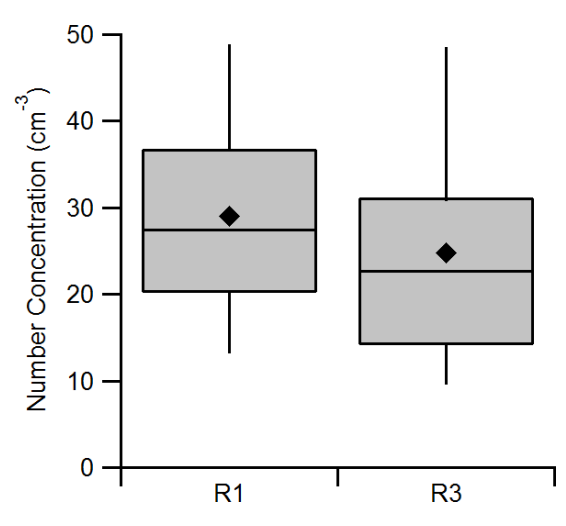

Fig. 14. Aerosol number concentrations $\left(0.1<D_{\mathrm{p}}<3 \mu \mathrm{m}\right)$ from the PCASP measured above (R1) and below (R3) the supercooled layer cloud. Whiskers extend to 5th and 95th percentiles, boxes encompass 25th to 75th percentiles and 50th percentiles are horizontal lines. Mean values are represented by black markers.

supercooled Arctic stratus clouds (Verlinde et al., 2007). The ice crystals in this cloud were predominantly around $1 \mathrm{~mm}$ in size and consisted of stellar and plate like habits. The formation of this ice at these relatively warm temperatures $\left(>-13^{\circ} \mathrm{C}\right.$ ) could be a result of either (a) all or some cloud droplets containing inefficient IN (which nucleate via a slow stochastic process) which are activated over time, or (b) entrainment of aerosol into cloud and/or droplets, a small fraction of which act as a more efficient IN. By inefficient IN, we mean IN which do not nucleate ice instantaneously at a given temperature and humidity, but may do so in the same environment given sufficient time. If the nucleation is triggered by a small number of efficient IN then in the absence of entrainment these will quickly be depleted by precipitation. These IN would thus have to be replenished through entrainment from directly above or below the stratus cloud, otherwise the cloud would soon contain liquid water only.

Significantly, an enhanced number of sub-micron aerosols were observed just above cloud top. The C-ToF-AMS measurements showed the bulk submicron non-refractory particulate mass consisted of a mixture of sulphate and carbonaceous material. Ground based observations in clouds on the Jungfraujoch mountain-top in Switzerland (Choularton et al., 2008; Targino et al., 2009) suggest that polluted air masses containing carbonaceous aerosol are associated with an increase in ice crystal concentration in clouds in this temperature range $\left(-10\right.$ to $\left.-12^{\circ} \mathrm{C}\right)$. It is possible that these particles are gradually being entrained into the cloud and acting as ice nuclei. The instrumentation used in this study could not confirm/rule out the presence of either mineral dust or biological particles. Both of these particle types have been shown to be efficient ice nuclei at colder temperatures (Connolly et al., 2009; DeMott et al., 2010). Biological particles could also be responsible for heterogenous ice nucleation at relatively warmer temperatures $\left(>-15^{\circ} \mathrm{C}\right.$, DeMott and Prenni, 2010).
Studies have demonstrated the ability of some organic compounds to form a glassy phase at low temperatures which can act as ice nuclei (Murray et al., 2010). Glassy organic aerosol particles have recently been detected at room temperatures (Virtanen et al., 2010), and these could also be a potential source of efficient ice nuclei at relatively warm temperatures. There is no evidence of dust out flow from Africa based on 7 day back trajectories generated from ECMWF wind field data.

Aerosol particle number concentrations $(0.1<$ Diameter $<3.0 \mu \mathrm{m})$ measured above/below cloud were of the order of $25 \mathrm{~cm}^{-3}$, whereas ice/precipitation concentrations in and below the layer cloud were around $0.2 \mathrm{~L}^{-1}$. Assuming an entrainment velocity of around $0.3 \mathrm{~cm} \mathrm{~s}^{-1}$ across the $\sim 4^{\circ} \mathrm{C}$ cloud top inversion (Moeng et al., 1999) results in a flux of around $8 \mathrm{~cm}^{-2} \mathrm{~s}^{-1}$ particles being entrained at cloud top. For an ice crystal concentration of $0.2 \mathrm{~L}^{-1}$ and assuming an ice crystal fall speed of $1 \mathrm{~m} \mathrm{~s}^{-1}$ (Mitchell, 1996) an ice particle loss rate of $0.02 \mathrm{~cm}^{-2} \mathrm{~s}^{-1}$ is calculated. Therefore if the entrained aerosols are acting as efficient IN to maintain the ice crystal population in the cloud, roughly 1 in every 400 particles entrained would need to be an IN at temperatures $>-12.0^{\circ} \mathrm{C}$. This would require an ambient IN population of about $62 \mathrm{~L}^{-1}$ at $>-12.0^{\circ} \mathrm{C}$, a value which is more than one, two and three orders of magnitude larger than that predicted by the Meyers, Fletcher and Cooper schemes respectively (DeMott et al., 2010). Uncertainties of a factor of 2 in entrainment velocities are not large enough to generate IN concentrations more in keeping with those reported in the literature. Also, it has been demonstrated that ambient IN concentrations are highly correlated with larger particles (Diameter $>0.5 \mu \mathrm{m}$, DeMott et al., 2010), which only represent a small fraction $(<1 \%)$ of the aerosol number concentrations measured. Therefore the argument that ice is formed in the stratus cloud via entrainment of IN from outside cloud seems highly unlikely. This lends weight to the argument that ice is formed via a slow stochastic process. The cloud in this case was observed to precipitate lightly for several hours, which drives the requirement for new ice formation. If the ice is formed through a sufficiently large number of in-efficient IN, then the source of IN from entrainment is not required.

An area of convective cloud initiated below the stratus cloud contained both liquid water droplets and ice particles. This convective feature was observed to be in steady state according to the radar reflectivity structure. The cloud was precipitating large rimed ice crystals. Large number concentrations of pristine column ice crystals were also measured in the region of the convective cloud, which must have formed not at cloud top but at around $-5^{\circ} \mathrm{C}$. There are a number of pieces of evidence for this. The ice appears to be smaller and less rimed at warmer temperatures than that at cloud top. Also, previous studies have demonstrated that needles/columns grow at temperatures above $-10^{\circ} \mathrm{C}$, whereas plates/stellars grow at colder cloud temperatures (Pruppacher 
and Klett, 1997). The vertical profile of ice crystal number concentration shows that the concentrations in the convective cloud are more than 10 times larger than in the mid-level stratus, despite both cloud tops being capped at the same level $\left(-12.2^{\circ} \mathrm{C}\right)$. Taking all these factors into account, it seems most likely that ice is forming in the convective region as a result of a SIP mechanism, most likely due to the process of splinter production during riming (the Hallett-Mossop process, HM, Hallett and Mossop, 1974). This process occurs when ice crystals accrete supercooled water droplets. The freezing of the supercooled droplets on the surface of the ice crystals can result in small ice splinters being ejected from the surface of the newly freezing drops due to the build up of large surface stresses. The process is at its most effective for rimer surface temperatures close to $-5^{\circ} \mathrm{C}$ (Pruppacher and Klett, 1997), the same temperature at which pristine columns are observed. In order for the process to occur both supercooled water and ice are needed. The HM process has been identified in several other studies as being an important mechanism for accounting for observed ice crystal concentrations (Blyth and Latham, 1997; Rangno and Hobbs, 2001; Hogan et al., 2002).

In this case the supercooled water is provided by the updraft within the convective cloud, while the initial rimer surface is provided by the ice crystals falling from the mid-level stratus (which formed via primary nucleation). After the formation of the ice splinters and their subsequent growth into pristine columns in the convective region due to the HM process, the columns continue to grow by vapour diffusion and riming until either their fall speed exceeds that of the updraft, or they reach the top of the cloud. At cloud top the ice is transported horizontally due to divergence of air at the inversion to a region of reduced updraft, where they can subsequently precipitate. These crystals then fall as large graupel type precipitation which is observed in proximity to the core liquid water updraft, and may participate in further SIP. It is highly likely that the HM process is responsible for the formation of precipitation which reaches the ground and that without this process the convective cloud would not be precipitating with rates of around $1 \mathrm{~mm} \mathrm{~h}^{-1}$ as observed by the operational rainfall radar. Therefore an accurate representation of this process in weather forecasting models could be important, as well as being needed to accurately predict the onset of ice formation in slightly supercooled clouds.

To quantitatively discuss whether the HM process could be responsible for the observed enhancement in ice crystal concentrations seen, we have adopted the approach of HarrisHobbs and Cooper (1987). Firstly, an ice crystal size distribution measured in the vicinity above the HM region was used to calculate the ice particle production rate that must have occurred to yield the concentration of ice crystals between 90 and $140 \mu \mathrm{m}$ length. These crystals have a linear growth rate of around $1.4 \mu \mathrm{m} \mathrm{s}^{-1}$ as described by Ryan et al. (1976).
Assuming that ice particles are constantly growing in a water saturated environment, if we are to have a steady state then a particle exiting this size range at $D=140 \mu \mathrm{m}$ must be replaced by one entering it at $D=90 \mu \mathrm{m}$. The time taken for that to occur, $\tau$, is the amount of growth $(\delta D=140-90=50 \mu \mathrm{m})$ divided by the growth rate $\left(1.4 \mu \mathrm{m} \mathrm{s}^{-1}\right), 35.7 \mathrm{~s}$. If we assume that the only source of ice crystals moving through this size range is ice splinters then the production rate is the number concentration of crystals in this size range, $\delta N$, divided by the time taken or $\delta N / \tau$. This yields a measured splinter production rate of $43 \mathrm{~m}^{-3} \mathrm{~s}^{-1}$.

Theoretically the riming rate of the ice particles as they fall through a supercooled cloud determines the ice splinter production rate. We chose to apply Eq. (1) from Harris-Hobbs and Cooper (1987) to the data from this study. For input we chose a supercooled liquid distribution from R6 $\left(-2.1^{\circ} \mathrm{C}\right)$ as measured with the CDP. This level was chosen as the input size distribution as it is outside the active region of the HM process and so likely unchanged by it. For the ice size distribution we used the measured ice size distribution within the stratus layer at $-12{ }^{\circ} \mathrm{C}$. As mentioned earlier, these ice crystals were comprised mainly of plates and stellars and so should have a smaller terminal velocity than graupel, but nevertheless still be capable of riming.

In order to complete the calculation, collection efficiencies between drops and ice particles were assumed to be 1 and the terminal velocities/densities of the crystals were derived using the approach of Heymsfield et al. (2002) for snow flakes. Inputs to the calculation of terminal velocity (area ratio and length) were taken from the 2DS probe image data. Using the mean drop size distribution for the in-cloud period with the constraint that only drops with diameter $D>24 \mu \mathrm{m}$ can produce splinters leads to a predicted splinter production rate of $0.01 \mathrm{~m}^{-3} \mathrm{~s}^{-1}$. This is lower than the measured rate of $43 \mathrm{~m}^{-3} \mathrm{~s}^{-1}$. Removing the constraint where only drops with $D>24 \mu \mathrm{m}$ allow splinter production to occur (to a situation where all droplets measured by the CDP can allow splinter production) results in a rate of $14 \mathrm{~m}^{-3} \mathrm{~s}^{-1}$, which is in better agreement with the measured production rate. The cloud droplet concentration in the convective region was highly variably resulting in an average number concentration of $\sim 7 \mathrm{~cm}^{-3}$. Predicted splinter production rates using the same shape spectrum but with higher total concentrations of droplets $\left(50 \mathrm{~cm}^{-3}\right.$, approximately the peak concentration observed) were 0.08 and $101 \mathrm{~m}^{-3} \mathrm{~s}^{-1}$ (with and without the $D>24 \mu \mathrm{m}$ constraint, respectively). The predicted production rates using the mean and peak droplet concentrations bound the measured production rate assuming drops with $D<24 \mu \mathrm{m}$ can produce splinters.

Using the collection efficiencies between drops and ice from Beard and Grover (1974) results in only small changes in predicted production rates $(<5 \%)$. The droplet spectrum used to calculate the predicted splinter rate was obtained at $-2.1^{\circ} \mathrm{C}$. While droplets would grow to larger sizes at colder temperatures in the convective cloud, measurements show 


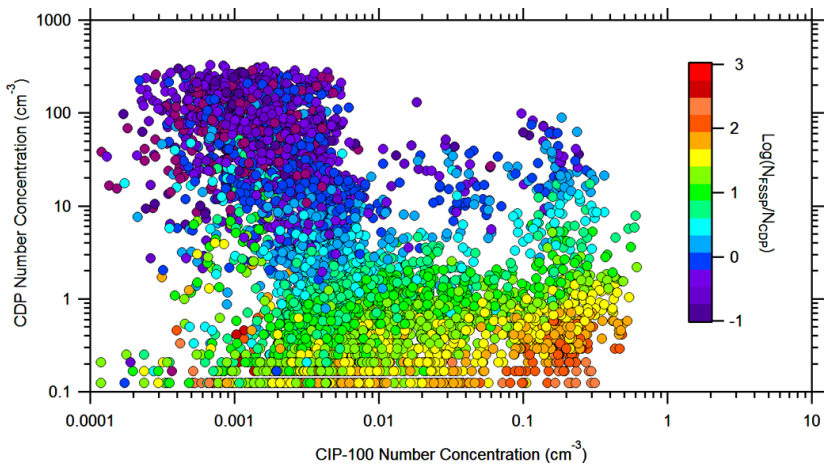

Fig. A1. CDP total number concentration as a function of CIP-100 total particle number concentration. Data are from flight B434 in a large frontal system. Data are coloured to the $\log _{10}$ of FSSP:CDP total number concentration ratio.

little increase in the number of droplets with $D>24 \mu \mathrm{m}$ at $-4.3^{\circ} \mathrm{C}$ relative to those at $-2.1^{\circ} \mathrm{C}$ (both concentrations are less than $0.1 \mathrm{~cm}^{-3}$ ). Therefore, predicted production rates using the $D>24 \mu \mathrm{m}$ criteria are not dependant on the size distribution used as measurements from relevant temperature levels lack significant numbers of large droplets. However, the lack of large droplets in the convective region may be a result of the evaporation of droplets in mixed phase conditions.

The predicted production rates also assume no recycling of ice splinters back into the HM zone for further splinter production. An estimation of this effect has been calculated by altering the total number concentration of the input ice size distribution of rimers by a factor of 100 (from 0.2 to $20 \mathrm{~L}^{-1}$ ). This results in a production rate $\sim 100$ times larger which is still below the measured production rate by around an order of magnitude if we maintain the $D>24 \mu \mathrm{m}$ criterion. However, it may be possible that for the large stellar/plate like crystals (the observed rimers in this case), the need for large drops $(>24 \mu \mathrm{m})$ may not be necessary for SIP production via the HM process as it is for graupel particles acting as the rimers. This will be further investigated in future laboratory studies.

\section{Appendix A}

\section{Cloud droplet measurements}

Both a Cloud Droplet Probe (CDP, Droplet Measurement Technology Inc) and a Forward Scattering Spectrometer Probe (FSSP) were installed on the BAe146. Both of these use forward scattered light intensity to determine cloud droplet size (1-50 $\mu \mathrm{m}$ in up to $40 \mathrm{bins})$. However the hardware containing the optics for the CDP is a greater distance from its sample area than for the FSSP, making it likely that the CDP is less prone to artefacts resulting from ice crystals

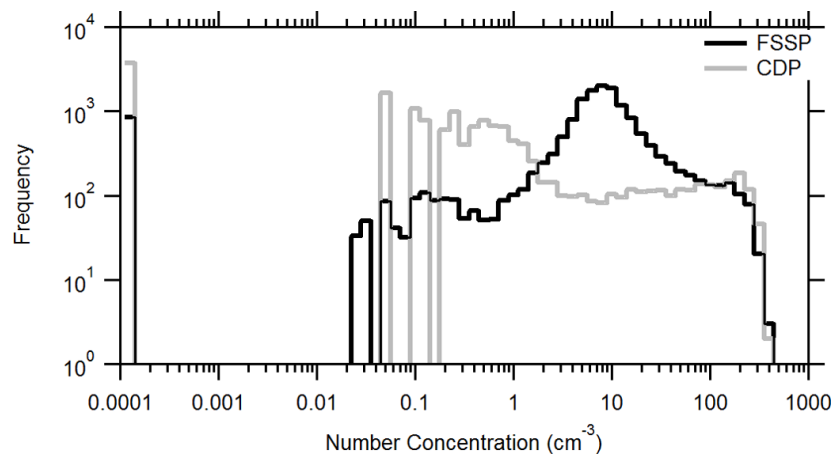

Fig. A2. Histogram of FSSP and CDP number concentrations measured in frontal cloud during flight B434.

shattering on the probe which is commonly seen on the FSSP. Figure A1 shows the measured cloud droplet concentration from the CDP as a function of the large cloud particle number concentration as measured by the CIP-100. Each data point is coloured to the $\log _{10}$ of the ratio of the FSSP to CDP number concentration. Values of 3 (red markers) are regions where the FSSP over-counts relative to the CDP by a factor of 1000 . The FSSP appears to overcount relative to the CDP in regions of high $\left(>5 L^{-1}\right)$ large particle concentrations as measured by the CIP-100. The ratio of detected cloud droplet concentrations from the FSSP and CDP is 1 (blue markers with $\log _{10}$ value of 0 ) when the ice crystal number concentrations measured by the CIP- 100 were below $\sim 5 L^{-1}$. This suggests that large ice crystals impacting and shattering on instruments affect the FSSP measurements more than the CDP. Shattering artefacts identified through the FSSP to CDP number concentration ratio appear to be small when droplet concentrations are high, suggesting the shattered fragments are greatly outnumbered by genuine droplets. Histograms of measured number concentration from the CDP and FSSP for the entire flight are shown in Fig. A2. This shows that both the FSSP and CDP show similar frequencies of high $\left(>50 \mathrm{~cm}^{-3}\right)$ particle concentrations. However, the FSSP shows a large mode centred at $10 \mathrm{~cm}^{-3}$ which is not evident in the CDP data. Instead, the CDP has a mode below $1 \mathrm{~cm}^{-3}$. The data shown in Fig. A1 and Fig. A2 are from a subsequent flight and not the study presented in the main article text. However, probe configurations were identical for both flights. The data presented in Fig. A1 and Fig. A2 are from a case with significantly larger ice mass concentrations/sizes, with ice being found over larger spatial scales. This makes the data from the case presented in the Appendix more suitable for identification of instrumentation artefacts. 


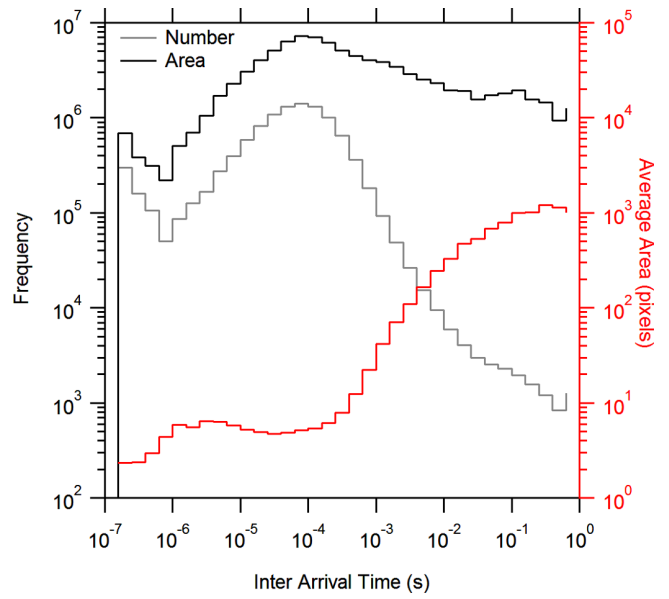

Fig. B1. Frequency histograms of particle interarrival time from the 2DS measured during flight B430. The "Number" curve (gray - weighted by number) and the "Area" curve (black - weighted by particle area) are plotted on the left axis. Average particle area is plotted in red on the right axis.

\section{Appendix B}

\section{OAP data processing}

Ice mass and number concentrations are calculated following an analysis of the raw images recorded from the OAPs (Optical Array Probes, specifically the 2DS). The particle statistics used to discriminate between liquid and ice are the total area of the particle and the perimeter around the edge of the particle. These parameters are adjusted to account for internal voids which alter particle areas and perimeters differently, and would cause out-of-focus circular particles to be classified as non-circular with the approach used. The definition of circularity (C) for the image analysis is shown in Eq. (B1), where $P$ is the measured particle perimeter, and $A$ is the measured particle Area. While the pixel width is constant and defined by the instrument optics, the pixel length is defined by the data acquisition rate and airspeed. Assuming the probes were acquiring data at the correct rate, pixels are square and the calculation of particle properties is simple. If the data acquisition rate is incorrect the pixels are no longer square the particle statistics need to be scaled to account for pixel stretching/compression. Particles with circularity greater than 1.25 are considered to be ice, and less than 1.25 considered liquid due to the compact nature of the image. A perfect circle has a circularity of 1 , with all other shapes having a larger value. This large circularity threshold for ice relative to the ideal value is required to prevent poorly imaged drizzle sized water drops from being counted as ice particles which leads to unrealistically high ice concentrations. Circularity values less than 1 are possible in practise due to the discretisation of images into pixels and images consisting of only a small number of pixels. Only particles with an area greater than 16 pixels are used in this analysis, as small images consisting of only a few pixels are not imaged with enough resolution to accurately determine shape. Images are rejected if any of the end elements on the OAP are occulted due to incomplete sizing as the sample area and size of partially viewed images is poorly defined. Ice mass concentrations were calculated from the maximum dimension of the ice crystal (measured in the along array or aircraft movement direction) using the parameterisation of Brown and Francis (1995). The separation of ice/liquid using circularity would count any round ice as being liquid but this is quite unlikely due to the non-circular shape of pristine ice, and also due to the rough surface of graupel and aggregates. The masses associated with the round and small classes of particles are calculated using the maximum width along the array as the particle diameter and assumes the particle was a perfect sphere. Round particles were size corrected due to being out of focus using the results of Korolev (2007). Small ice (approx $<80 \mu \mathrm{m}$ diameter) cannot be determined from the OAPs (due to the size threshold for analysis) nor from the $\mathrm{CDP}$ as there are no measurements of a parameter associated with phase. Particles detected within an interarrival time less than $10 \mu \mathrm{s}$ (relating to roughly $1 \mathrm{~mm}$ distance during flight) are also rejected as they are most likely a result of particle shattering on the OAP inlet. This has been seen in other studies (Field et al., 2006). The inter-arrival time threshold was determined from examining the inter-arrival time histogram for the entire flight (see Fig. B1). The derived number concentrations are not sensitive to small changes in the interarrival time threshold.

$C=\frac{P^{2}}{4 \pi A}$

Acknowledgements. This work was funded by the NERC APPRAISE programme, grant number NE/E01125X/1. We would like to acknowledge the support from FGAM, FAAM and Direct Flight in obtaining the aircraft dataset. We would also like to thank the following for supporting the CFARR measurements: Andrew Barrett (University of Reading), Darcy Ladd and Charles Wrench (CFARR). MODIS data were obtained from the NASA LAADS online archive (http://ladsweb.nascom.nasa.gov/). Digital Elevation Maps were obtained from the USGS GTOPO30 dataset, and coastline data were obtained from the online NOAA coastline extractor (http://rimmer.ngdc.noaa.gov/). Surface pressure fields were obtained from the ECMWF Interim Re-Analysis archive (http://data.ecmwf.int/data/). Radiosonde data were obtained from the University of Wyoming Sounding Archive (http://weather.uwyo.edu/upperair/sounding.html). We would like to acknowledge the UK Met Office for the CIP-100 data. We also acknowledge the British Atmospheric Data Centre for the backtrajectory data (http://badc.nerc.ac.uk/community/trajectory/).

Edited by: M. Petters 


\section{References}

Baumgardner, D., Jonsson, H., Dawson, W., O'Connor, D., and Newton, R.: The cloud, aerosol and precipitation spectrometer: a new instrument for cloud investigations, Atmos. Res., 59-60, 251-264, 2001.

Beard, K. V. and Grover, S. N.: Numerical collision efficiencies for small raindrops colliding with micron size particles, J. Atmos. Sci., 31, 543-550, 1974.

Blyth, A. M. and Latham, J.: A multi-thermal model of cumulus glaciation via the Hallett-Mossop process, Q. J. Roy. Meteorol. Soc., 123, 1185-1198, 1997.

Bretherton, C. S., Uttal, T., Fairall, C. W., Yuter, S. E., Weller, R. A., Baumgardner, D., Comstock, K., Wood, R., and Raga, G. B.: The EPIC 2001 stratocumulus study, B. Am. Meteorol. Soc., 85, 967977, 2004.

Brown, P. R. A. and Francis, P. N.: Improved measurements of the ice water-content in cirrus using a total-water probe, J. Atmos. Ocean. Tech., 12, 410-414, 1995.

Canagaratna, M. R., Jayne, J. T., Jimenez, J. L., Allan, J. D., Alfarra, M. R., Zhang, Q., Onasch, T. B., Drewnick, F., Coe, H., Middlebrook, A., Delia, A., Williams, L. R., Trimborn, A. M., Northway, M. J., DeCarlo, P. F., Kolb, C. E., Davidovits, P., and Worsnop, D. R.: Chemical and microphysical characterization of ambient aerosols with the aerodyne aerosol mass spectrometer, Mass Spectrom. Rev., 26, 185-222, 2007.

Choularton, T. W., Bower, K. N., Weingartner, E., Crawford, I., Coe, H., Gallagher, M. W., Flynn, M., Crosier, J., Connolly, P., Targino, A., Alfarra, M. R., Baltensperger, U., Sjogren, S., Verheggen, B., Cozic, J., and Gysel, M.: The influence of small aerosol particles on the properties of water and ice clouds, Faraday Discuss., 137, 205-222, 2008.

Clark, P. D., Choularton, T. W., Brown, P. R. A., Field, P. R., Illingworth, A. J., and Hogan, R. J.: Numerical modelling of mixedphase frontal clouds observed during the CWVC project, Q. J. Roy. Meteor. Soc., 131, 1677-1693, 2005.

Connolly, P. J., Möhler, O., Field, P. R., Saathoff, H., Burgess, R., Choularton, T., and Gallagher, M.: Studies of heterogeneous freezing by three different desert dust samples, Atmos. Chem. Phys., 9, 2805-2824, doi:10.5194/acp-9-2805-2009, 2009.

Crosier, J., Allan, J. D., Coe, H., Bower, K. N., Formenti, P., and Williams, P. I.: Chemical composition of summertime aerosol in the Po Valley (Italy), Northern Adriatic and Black Sea, Q. J. Roy. Meteor. Soc., 133, 61-75, 2007.

DeMott, P. J. and Prenni, A. J.: New Directions: Need for defining the numbers and sources of biological aerosols acting as ice nuclei, Atmos. Environ., 44, 1944-1945, 2010.

DeMott, P. J., Prenni, A. J., Liu, X., Kreidenweis, S. M., Petters, M. D., Twohy, C. H., Richardson, M. S., Eidhammer, T., and Rogers, D. C.: Predicting global atmospheric ice nuclei distributions and their impacts on climate, Proc. Natl. Acad. Sci., 107(25), 11217-11222, doi:10.1073/pnas.0910818107, 2010.

Field, P. R., Heymsfield, A. J., and Bansemer, A.: Shattering and particle interarrival times measured by optical array probes in ice clouds, J. Atmos. Ocean. Tech., 23, 1357-1371, 2006.

Goddard, J. W. F., Eastment, J. D., and Thurai, M.: The Chilbolton advanced meteorological radar - a tool for multidisciplinary atmospheric research, Electron. Comm. Eng., 6, 77-86, 1994.

Hallett, J. and Mossop, S. C.: Production of secondary ice particles during riming process, Nature, 249, 26-28, 1974.
Harris-Hobbs, R. L. and Cooper, W. A.: Field evidence supporting quantitative predictions of secondary ice production-rates, J. Atmos. Sci., 44, 1071-1082, 1987.

Heymsfield, A. J., Bansemer, A., Field, P. R., Durden, S. L., Stith, J. L., Dye, J. E., Hall, W., and Grainger, C. A.: Observations and parameterizations of particle size distributions in deep tropical cirrus and stratiform precipitating clouds: results from in situ observations in TRMM field campaigns, J. Atmos. Sci., 59, 3457-3491, 2002.

Hogan, R. J., Field, P. R., Illingworth, A. J., Cotton, R. J., and Choularton, T. W.: Properties of embedded convection in warmfrontal mixed-phase cloud from aircraft and polarimetric radar, Q. J. Roy. Meteor. Soc., 128, 451-476, 2002.

Hogan, R. J., Francis, P. N., Flentje, H., Illingworth, A. J., Quante, M., and Pelon, J.: Characteristics of mixed-phase clouds. I: Lidar, radar and aircraft observations from CLARE'98, Q. J. Roy. Meteor. Soc., 129, 2089-2116, $2003 \mathrm{a}$.

Hogan, R. J., Illingworth, A. J., O'Connor, E. J., and Baptista, J. P. V. P.: Characteristics of mixed-phase clouds. II: A climatology from ground-based lidar, Q. J. Roy. Meteorol. Soc., 129, 2117-2134, 2003b.

Hogan, R. J., Behera, M. D., O'Connor, E. J., and Illingworth, A. J.: Estimate of the global distribution of stratiform supercooled liquid water clouds using the LITE lidar, Geophys. Res. Lett., 31, L05106, 2004.

Huang, Y. H., Blyth, A. M., Brown, P. R. A., Choularton, T. W., Connolly, P., Gadian, A. M., Jones, H., Latham, J., Cui, Z. Q., and Carslaw, K.: The development of ice in a cumulus cloud over Southwest England, New J. Phys., 10, 10521, 2008.

Illingworth, A. J., Hogan, R. J., O’Connor, E. J., Bouniol, D., Brooks, M. E., Delanoe, J., Donovan, D. P., Eastment, J. D., Gaussiat, N., Goddard, J. W. F., Haeffelin, M., Baltink, H. K., Krasnov, O. A., Pelon, J., Piriou, J. M., Protat, A., Russchenberg, H. W. J., Seifert, A., Tompkins, A. M., van Zadelhoff, G. J., Vinit, F., Willen, U., Wilson, D. R., and Wrench, C. L.: Cloudnet - continuous evaluation of cloud profiles in seven operational models using ground-based observations, B. Am. Meteorol. Soc., 88, 883-898, 2007.

Klein, S. A., McCoy, R. B., Morrison, H., Ackerman, A. S., Avramov, A., de Boer, G., Chen, M. X., Cole, J. N. S., Del Genio, A. D., Falk, M., Foster, M. J., Fridlind, A., Golaz, J. C., Hashino, T., Harrington, J. Y., Hoose, C., Khairoutdinov, M. F., Larson, V. E., Liu, X. H., Luo, Y. L., McFarquhar, G. M., Menon, S., Neggers, R. A. J., Park, S., Poellot, M. R., Schmidt, J. M., Sednev, I., Shipway, B. J., Shupe, M. D., Spangenbery, D. A., Sud, Y. C., Turner, D. D., Veron, D. E., von Salzen, K., Walker, G. K., Wang, Z. E., Wolf, A. B., Xie, S. C., Xu, K. M., Yang, F. L., and Zhang, G.: Intercomparison of model simulations of mixed-phase clouds observed during the ARM Mixed-Phase Arctic Cloud Experiment. I: Single-layer cloud, Q. J. Roy. Meteorol. Soc., 135, 979-1002, 2009.

Knollenberg, R. G.: Techniques for probing cloud microstructure, in: Clouds, Their Formation, Optical Properties, and Effects, edited by: Hobbs, P. V. and Deepak, A., Academic Press, New York, USA, 15-91, 1981.

Korolev, A.: Reconstruction of the sizes of spherical particles from their shadow images. Part I: Theoretical considerations, J. Atmos. Ocean. Tech., 24, 376-389, 2007.

Lawson, R. P., O’Connor, D., Zmarzly, P., Weaver, K., Baker, B., 
Mo, Q. X., and Jonsson, H.: The 2D-S (Stereo) probe: design and preliminary tests of a new airborne, high-speed, high-resolution particle imaging probe, J. Atmos. Ocean. Tech., 23, 1462-1477, 2006.

Marshall, J. S. and Palmer, W. M.: The distribution of raindrops with size, J. Meteorol., 5, 165-166, 1948.

McFarquhar, G. M., Um, J., Freer, M., Baumgardner, D., Kok, G. L., and Mace, G.: Importance of small ice crystals to cirrus properties: observations from the Tropical Warm Pool International Cloud Experiment (TWP-ICE), Geophys. Res. Lett., 34, L13803, doi:10.1029/2007GL029865, 2007.

Meyers, M. P., Demott, P. J., and Cotton, W. R.: New primary icenucleation parameterizations in an explicit cloud model, J. Appl. Meteorol., 31, 708-721, 1992.

Mitchell, D. L.: Use of mass- and area-dimensional power laws for determining precipitation particle terminal velocities, J. Atmos. Sci., 53, 1710-1723, 1996.

Moeng, C. H., Sullivan, P. P., and Stevens, B.: Including radiative effects in an entrainment rate formula for buoyancy-driven PBLs, J. Atmos. Sci., 56, 1031-1049, 1999.

Möhler, O., Field, P. R., Connolly, P., Benz, S., Saathoff, H., Schnaiter, M., Wagner, R., Cotton, R., Krämer, M., Mangold, A., and Heymsfield, A. J.: Efficiency of the deposition mode ice nucleation on mineral dust particles, Atmos. Chem. Phys., 6, 3007-3021, doi:10.5194/acp-6-3007-2006, 2006.

Mossop, S. C. and Hallett, J.: Ice crystal concentration in cumulus clouds - influence of drop spectrum, Science, 186, 632-634, 1974.

Murray, B. J., Wilson, T. W., Dobbie, S., Cui, Z., AlJumur, S. M. R. K., Mohler, O., Schnaiter, M., Wagner, R., Benz, S., Niemand, M., Saathoff, H., Ebert, V., Wagner, S. and Karcher, B.: Heterogeneous nucleation of ice particles on glassy aerosols under cirrus conditions, Nat. Geosci., 4, 233-237, 2010.
Pruppacher, H. R. and Klett, J. D.: Microphysics of Clouds and Precipitation, Kluwer Acad., Norwell, MA, USA, 18, 42-44, 1997.

Ramanathan, V., Cess, R. D., Harrison, E. F., Minnis, P., Barkstrom, B. R., Ahmad, E., and Hartmann, D.: Cloud-radiative forcing and climate - results from the Earth Radiation Budget Experiment, Science, 243, 57-63, 1989.

Rangno, A. L. and Hobbs, P. V.: Ice particles in stratiform clouds in the Arctic and possible mechanisms for the production of high ice concentrations, J. Geophys. Res.-Atmos., 106, 15065-15075, 2001.

Ryan, B. F., Wishart, E. R., and Shaw, D. E.: Growth-rates and densities of ice crystals between $-3{ }^{\circ} \mathrm{C}$ and $-21^{\circ} \mathrm{C}$, J. Atmos. Sci., 33, 842-850, 1976.

Targino, A. C., Coe, H., Cozic, J., Crosier, J., Crawford, I., Bower, K., Flynn, M., Gallagher, M., Allan, J., Verheggen, B., Weingartner, E., Baltensperger, U., and Choularton, T.: Influence of particle chemical composition on the phase of cold clouds at a high-alpine site in Switzerland, J. Geophys. Res.-Atmos., 114, D18206, doi:10.1029/2008JD011365, 2009.

Verlinde, J., Harrington, J. Y., McFarquhar, G. M., Yannuzzi, V. T., Avramov, A., Greenberg, S., Johnson, N., Zhang, G., Poellot, M. R., Mather, J. H., Turner, D. D., Eloranta, E. W., Zak, B. D., Prenni, A. J., Daniel, J. S., Kok, G. L., Tobin, D. C., Holz, R., Sassen, K., Spangenberg, D., Minnis, P., Tooman, T. P., Ivey, M. D., Richardson, S. J., Bahrmann, C. P., Shupe, M., DeMott, P. J., Heymsfield, A. J., and Schofield, R.: The mixedphase Arctic cloud experiment, B. Am. Meteorol. Soc., 88, 205221, 2007.

Virtanen, A., Joutsensaari, J., Koop, T., Kannosto, J., Yli-Pirila, P., Leskinen, J., Makela, J. M., Holopainen, J. K., Poschl, U., Kulmala, M., Worsnop, D. R. and Laaksonen, A.: An amorphous solid state of biogenic secondary organic aerosol particles, Nature, 467, 824-827, 2010. 